
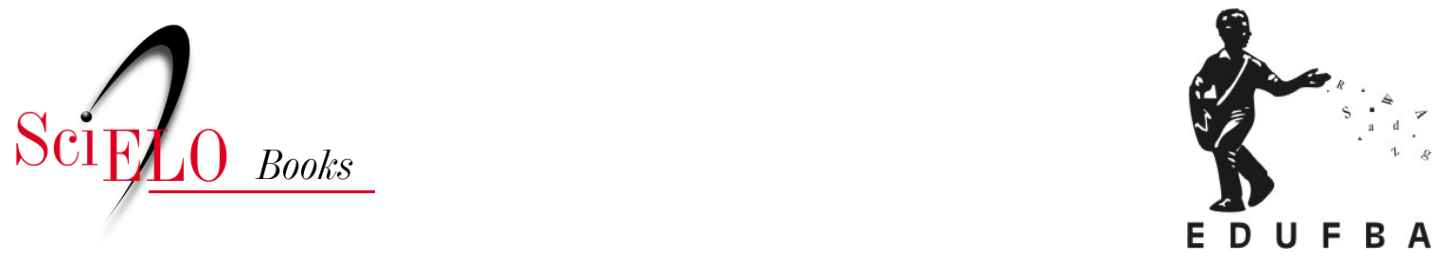

\title{
Em busca de uma outra gestão
}

\author{
Genauto Carvalho de França Filho \\ Philippe Eynaud
}

\section{SciELO Books / SciELO Livros / SciELO Libros}

FRANÇA FILHO, G. C., and EYNAUD, P. Em busca de uma outra gestão. In.: Solidariedade e organizações: pensar uma outra organização [online]. Salvador: EDUFBA; Ateliê de Humanidades, 2020, pp. 203-264. ISBN: 978-65-5630-199-0. https://doi.org/10.7476/9786556301990.0005.

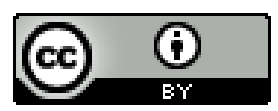

All the contents of this work, except where otherwise noted, is licensed under a Creative Commons Attribution 4.0 International license.

Todo o conteúdo deste trabalho, exceto quando houver ressalva, é publicado sob a licença Creative Commons Atribição 4.0.

Todo el contenido de esta obra, excepto donde se indique lo contrario, está bajo licencia de la licencia Creative Commons Reconocimento 4.0. 


\section{Em busca de uma outra gestão}

Este capítulo é uma oportunidade de retornar à dupla insustentabilidade mencionada na introdução deste livro. Propomos detalhar aqui a análise de duas propostas ricas no plano de uma gestão substantiva, ou seja, de uma gestão solidária e sustentável. A primeira é sul-americana. É a escola brasileira de pensamento sobre gestão social. Um debate rico e antigo o anima. Pode aparecer como uma resposta conceitual e prática de um país caracterizado historicamente por fortes desigualdades. A segunda é norte-americana. Trata-se da gestão dos bens comuns. Se inscrevendo na linha dos trabalhos de Ostrom, essa escola de pensamento partiu inicialmente de problemáticas ligadas à preservação de áreas naturais, mas não se limitou a estas. Veremos como essas duas escolas de pensamento diferem e se complementam. A dimensão prática dessas duas proposições nos ajudará a definir o campo que estamos propondo nomear como "a outra gestão".

\section{A ESCOLA BRASILEIRA DE GESTÃO SOCIAL}

A conceituação em torno da gestão social remonta à década de I990. (FRANCA FILHO, BOULLOSA, 2OI5) A gestão social encontrou significativa notoriedade na América Latina e, mais precisamente, no Brasil, embora permaneça profundamente europeia na escolha de suas referências acadêmicas. Podemos nos perguntar sobre a falta de sua maior difusão internacional. A barreira do idioma é provavelmente uma primeira explicação. Suas pesquisas se expressam sobretudo em português e não podem se beneficiar da mesma difusão que uma escrita em inglês. Mas isso não explica tudo. Sua posição distante da visão orto- 
doxa em matéria de gestão parece sem dúvida uma outra razão para sua menor difusão internacional.

Historicamente, o início da reflexão começou em um contexto internacional em torno de um treinamento ministrado por professores sul-americanos no âmbito do Banco Interamericano de Desenvolvimento. A formação buscou inicialmente explorar o conteúdo possível de uma gestão social em uma perspectiva neoliberal. Essa reflexão continuou no contexto brasileiro muito além da formação. Ela assumiu uma posição crítica iniciando uma reflexão organizacional em articulação com os conceitos de espaço público e de ação pública. No final dos anos I990, três subgrupos de pesquisa se distinguiram por seus objetos: democracia, território e terceiro setor. Depois disso, o conceito de gestão social começou a ampliar sua audiência com professores de gestão e políticas públicas, estudantes e atores em campo. A popularidade do conceito foi apoiada pela possibilidade de uma gestão orientada para a deliberação democrática e a interação entre o estado e a sociedade civil. Em 2007, a comunidade de pesquisadores e profissionais de gestão social decidiu criar um encontro nacional anual. Desde então, a comunidade continuou a crescer com a criação de formações e diplomas universitários e com a publicação de periódicos e livros especializados. Desde então, a comunidade de pesquisadores questiona a possibilidade de validar a existência de um campo de conhecimento associado a uma disciplina. (ARAÚJO, 20I4)

No que diz respeito ao seu conteúdo e substância, o conceito de gestão social revela-se complexo, pois combina uma dimensão analítica com uma dimensão prática. Ele também atende a uma dupla expectativa: assim, pode ao mesmo tempo atender às necessidades de organizações cujos objetivos não são econômicos e aquelas que buscam desenvolver uma resposta social em seu ambiente. Isso leva a análise à exploração de diferentes racionalidades e diferentes arranjos institucionais. O conceito de gestão social também possui caráter heurístico, pois permite articular na prática o econômico e o social. A gestão social também assume uma postura de recusa em relação à redução da organização à sua instrumentalização, do social ao econômico e 
do econômico ao mercado. (FRANÇA FILHO, 2003) Para isso, a gestão social visa tornar visível a pluralidade de recursos em uma economia substantiva.

\section{A gestão social e o espaço público}

Fernando Tenório, pesquisador brasileiro, vinculou a gestão social ao conceito de espaço público em Arendt e Habermas. Para ele, a gestão social adota a ideia de que deve haver espaços de deliberação para reconectar pessoas privadas com a ação pública. (TENÓRIO, 1998) Assim, a gestão social não pode ser um espaço de coerção. Para isso, atenção especial deve ser dada à inteligibilidade da linguagem, à transparência do dispositivo dialógico e às condições de emancipação dos atores associados aos debates.

Nesse contexto, a contribuição de Cançado, Pereira e Tenório (2015) é de mobilizar o conceito de "interesse bem compreendido" em Tocqueville, segundo o qual em uma sociedade democrática o interesse particular se une ao interesse geral. Diferentemente da noção de "mão invisível" em Smith, o "interesse bem compreendido" de Tocqueville levanta a questão do sujeito político. Desse modo, a gestão social se apresenta como a organização de um espaço público no qual os atores podem participar de sua própria emancipação enquanto inventam novas abordagens para resolver os problemas que se colocam na dinâmica do próprio coletivo. É assim que a gestão social também pode ser abordada através da coprodução de bens e serviços públicos em espaços democráticos, reunindo autoridades locais e atores da sociedade civil. Trata-se de se opor ao new public management, instaurando um ciclo virtuoso entre coprodução e inovação social. A gestão social se concebe, assim, como mediadora das relações entre atores no nível local, numa perspectiva de enriquecimento do espaço público.

\section{A gestão social e a ação pública}

Para a gestão social, a ação pública pode ser realizada por uma instituição pública ou por uma associação que defenda o interesse geral. Ambas as opções são possíveis. Na prática, isso possibilita renovar a orientação das políticas 
públicas locais, envolvendo atores associativos e coletivos de cidadãos. Conceitualmente, a gestão social abre duas perspectivas de análise. Na primeira, é uma questão de optar por uma orientação de sociedade. A gestão social tende então a se confundir tendencialmente com a "gestão pública da sociedade". (FRANÇA FILHO, 2003; FRANÇA FILHO; BOULLOSA, 2OI5) Trata-se de ampliar e estender a análise organizacional para proporcionar uma dimensão mais sociopolítica. Ao abrir essa perspectiva, o conceito de gestão social permite compreender o papel da sociedade civil e as iniciativas das organizações populares como sistemas auto-organizados, diretamente relacionados às demandas e serviços da própria sociedade. (FRANÇA FILHO, 2003; FRANÇA FILHO; BOULLOSA, 2015) O risco de deriva do projeto ou de instrumentalização desse tipo de projeto ainda está presente e requer várias precauções. Na segunda perspectiva, a ação coletiva e a ação pública são sobrepostas em favor de um sistema de políticas públicas de múltiplas partes interessadas. Estamos perto da proposta de Cefaï sobre ação coletiva definida como "qualquer tentativa de construir um coletivo, mais ou menos formalizado e institucionalizado, por indivíduos que buscam atingir um objetivo comum, em contextos de cooperação e de competição com outros coletivos". (CEFAÏ, 2007, p. 8) Os coletivos enfrentam problemas de alcance público e procuram resolvê-los implantando o que parecem ser enquetes sociais. (DEWEY, 1967)

As duas perspectivas se reúnem para definir os contornos de uma gestão social suscetível de enriquecer o leque de políticas públicas locais em termos de compartilhamento com os habitantes. Sua contribuição é, então, vinculada a "um conjunto de processos e dinâmicas que ativam e moldam (no âmbito das políticas públicas) uma comunidade de atores motivados pelo interesse público, pela resolução de problemas importantes ou pela preservação de bens públicos". (FRANÇA FILHO, BOULLOSA, 20I5, p. 208)

\section{A gestão social e a governança}

Ao combinar as questões de espaço público e de ação pública, o enriquecimento da democracia local é favorecido em uma perspectiva radical. 
Trata-se de oferecer aos indivíduos novas formas de autonomia. Em uma abordagem de democracia radical, a gestão social busca criar uma governança inclusiva, na qual todos possam participar das decisões que lhes dizem respeito. A gestão social entende, assim, demarcar-se da tutela de especialistas solicitados a iluminar a tomada de decisões dos coletivos de atores, para não decidir por eles. Retoma-se neste ponto o debate iniciado entre Dewey e Lippman sobre o status de especialista - expert - que mencionamos anteriormente. (DEWEY, 20IO) A gestão social se posiciona do lado de Dewey na esperança de modalidades de governança que permitam a emancipação dos atores e sua autonomia na tomada de decisões. O arcabouço teórico da gestão social não investiu muito no campo da governança. Isso o diferencia da corrente de pensamento sobre os bens comuns.

\section{A GESTÃO E A GOVERNANÇA DOS BENS COMUNS}

Do ponto de vista das relações de solidariedade e da organização, a teoria dos bens comuns é particularmente interessante porque é complementar à gestão social. Se as combinarmos, responderemos perfeitamente às questões levantadas na introdução deste livro. Enquanto a gestão social tem sua origem na solidariedade entre os humanos, o ponto de partida do pensamento de Ostrom reside no estudo da solidariedade entre os humanos e a natureza. Assim, os trabalhos de Ostrom e sua equipe são iniciados no estudo de bens comuns naturais, como pesca, sistemas de irrigação, florestas etc. Ostrom procura analisar e entender como os coletivos auto-organizados em torno desses recursos naturais podem estabelecer mecanismos de gestão perenes, portanto, sustentáveis. (OSTROM, 20IOa)

A emergência de uma auto-organização supõe a livre interação dos atores locais, espaços para discussão e formas de resolução de conflitos. A abordagem de Ostrom é pragmática. Ela parte do campo empírico e observa modos não hierárquicos de governança implementados em torno dos recursos naturais que são explorados e geridos localmente. O que Ostrom vai encontrar nesses diferentes campos de observação é uma grande diversidade de formas de 
ação coletiva e arranjos institucionais. (OSTROM, 2005) Sua hipótese, como ressalta Orsi, é que "se deixarmos os membros de um grupo dispor livremente de sua organização, eles serão capazes de organizar progressivamente um sistema eficaz e adaptivo". (ORSI, 20I5) Os bens comuns se caracterizam, para Ostrom, por um longo processo de adaptação, de ajuste, de tentativa e erro. Isso oferece as condições necessárias para o esclarecimento do interesse geral e sua defesa diante de interesses particulares. As formas auto-organizadas dos bens comuns são, portanto, superiores às lógicas do mercado para a preservação de recursos. Para sua demonstração, Ostrom passa por etapas conceituais sucessivas que remetem aos problemas teóricos levantados por campos distintos do conhecimento, porém vizinhos: o terceiro setor, a economia social e a economia solidária. (LAVILLE; EYNAUD, 20I8)

\section{Terceiro setor e recursos compartilhados}

A economia padrão faz do mercado o princípio pelo qual seria desejável estruturar as relações econômicas. Essa inegável preferência pelo mercado não nega a existência de outros bens. A economia ortodoxa reconhece a presença e a existência de bens públicos - como a defesa nacional, por exemplo. Para formular sua própria proposta, Ostrom alonga a lista de exceções à lógica do mercado. Ostrom e seu marido propõem uma tipologia que permite ampliar a categoria de bens, para além dos bens privados e dos bens públicos. Eles tomam a proposta de McNutt em termos de bens de clube como ponto de partida e, assim, desenham uma matriz que distingue os bens cruzando dois critérios: rivalidade e excludência. (OSTROM, OSTROM, I977) Isso leva a aparecer de maneira lógica os bens comuns - chamados common pool resources - como bens rivais e não excludentes, ao lado dos bens privados - rivais e excludentes -, dos bens públicos - não rivais e não excludentes - e dos bens de clube - bens excludentes e não rivais, como, por exemplo, os canais a cabo privados. 
Quadro 4 - Tipologia dos bens

\begin{tabular}{|l|l|l|}
\hline Bens & Excludentes & Não Excludentes \\
\hline Rivais & Bens privados & Bens comuns \\
\cline { 2 - 3 } & $\begin{array}{l}\text { Alimentos, roupas, carros, } \\
\text { estacionamento }\end{array}$ & Pescas, Florestas, Carvão \\
\hline Não Rivais & Bens de clube & Bens Públicos \\
\cline { 2 - 3 } & Cinemas, parques privados, TV a cabo & TV aberta, ar, defesa nacional \\
\hline
\end{tabular}

Fonte: adaptado de Ostrom e Ostrom (1977).

A não excludência de acesso e a rivalidade significam que os atores estão competindo pelo recurso e que potenciais passageiros clandestinos - free riders - podem vir retirá-los e capturá-los às custas de todos os outros. (HESS; RUTH, 2006) Assim, Hardin foi capaz de desenvolver a ideia segundo a qual haveria uma "tragédia dos comuns". (HARDIN, I968) Ostrom se diferencia profundamente em relação à Hardin. Todo o seu trabalho vai permitir desenvolver a tese inversa. Ostrom mostrará que uma governança específica - não redutível ao mercado - é capaz de preservar os bens comuns contra a tragédia do mercado.

De acordo com a mesma lógica de adicionar categorias, o terceiro setor baseia-se no reconhecimento de organizações não redutíveis a organizações privadas e a organizações públicas. Essas organizações participam de um terceiro campo - o terceiro setor -, que acolhe, sobretudo, serviços com uma forte dimensão relacional, como creches ou ajuda domiciliar. Nesse campo de atividade, o provedor desfruta de uma posição de força em relação ao consumidor em virtude das assimetrias de informação que o favorecem. Assim, quando um dos pais confia seu bebê a uma creche, é difícil para ele ou ela saber à noite - quando o pai ou a mãe o recupera -, se a prestação do serviço foi de qualidade ou não. O pagador do serviço - os pais - não é o destinatário do serviço e o bebê não pode relatar com precisão o desenrolar do seu dia. Nessa configuração, o provedor pode ficar tentado a oferecer um serviço de menor qualidade pelo mesmo preço. A assimetria de informações entre o provedor 
de serviços e o pagador bloqueia os mecanismos regulatórios do mercado. Nessa configuração, a organização sem fins lucrativos é bem-vinda. Ele envia os sinais esperados pelos pais para esses mercados específicos. Se a organização não é guiada pela busca do lucro, o oportunismo do prestador de serviços será menor e a entrega de melhor qualidade.

Com base nessas propostas, os bens comuns e as organizações do terceiro setor reivindicam sua existência ao lado do mercado e do Estado. Os dois quadros teóricos o fazem de acordo com os critérios aceitos pela economia ortodoxa. Isso significa que a economia padrão, longe de se reduzir ao discurso do mercado acima de tudo, examina as condições sob as quais se mostra legítimo encontrar as soluções pela intermediação dos bens comuns e/ou do terceiro setor. Não se trata, contudo, de uma renúncia aos postulados ortodoxos. Mesmo que os bens comuns e o terceiro setor sejam reconhecidos pela economia padrão, o mercado permanece visto como a resposta pertinente e a hipótese da racionalidade individual maximizadora não é contestada. Se as escolhas de organização são diversas, todas são explicadas pela busca do interesse pessoal. A lógica é atomística no sentido de que as interdependências entre atores são traduzidas por meio de comparações estabelecidas por cada um deles, sem comunicação ou deliberação coletiva. Como resultado, as instituições emanam de cálculos de custo-benefício e só são mantidas se demonstrarem eficácia na adaptação a ambientes em mudança. A racionalidade estratégica e instrumental que caracteriza a ação humana nesse paradigma impede a consideração de qualquer motivação política. Esse utilitarismo é impermeável aos dados sociológicos e a história que promove é marcada pelo determinismo econômico. A classificação pela natureza dos bens e serviços também sugere que existem qualidades intrínsecas que diferenciam bens privados, públicos e comuns, da mesma forma que existem atividades de mercado, de estado ou do terceiro setor. Como resultado, os bens comuns e as organizações do terceiro setor permanece sendo abordadas na sua dimensão residual. 


\section{Economia social e regime comum de propriedade}

Uma vez adquirido o reconhecimento de uma categoria adicional de bens comuns ao lado de bens públicos e privados, o desafio de Ostrom é entender como eles podem ser geridos de maneira durável ou sustentável. Para isso, um segundo nível do seu pensamento é sobre o estudo do que ela chamará de pacote de direitos - bundle o rights. Trata-se de saber como se regulam os direitos de acesso ao recurso, os direitos de apropriação dos produtos do recurso, os direitos de gestão do recurso, o direito de determinar quem terá os direitos de acesso e como eles podem ser transferidos. A pluralidade desses direitos determina a pluralidade institucional que ela observa na realidade. A análise dos direitos que se atribui uma comunidade auto-organizada de gerenciar seu recurso compartilhado permite que Ostrom abra a questão da propriedade coletiva. (NYSSENS, PETRELLA, 20I5) Ao fazer isso, ela se distancia da teoria ortodoxa. Ela constata que a prevenção contra as ameaças dos passageiros clandestinos - free riders - aumenta com a capacidade da comunidade de produzir regras para si e por si mesma. (OSTROM, 20IOa)

Nessa perspectiva, Ostrom retém na análise de Olson a necessidade de se apoiar em pequenos coletivos (OLSON, 1965), únicos capazes de desenvolver ao mesmo tempo mecanismos de entendimento, elaboração de regras e mecanismos eficazes de monitoramento e de controle. (OSTROM, 20IOa) Ostrom nota que o pequeno tamanho dos coletivos facilita a deliberação, a vigilância e o cumprimento das regras que foram acordadas. Há, nesse ponto, uma afirmação das virtudes do localismo e um desejo de desenvolver uma análise institucional de nível mais fino. (ORSI, 20I5) Segundo Laville e Salmon (20I5b), Ostrom se afasta assim do "neoinstitucionalismo de Williamson para se aproximar do institucionalismo histórico de Commons e Veblen". (LAVILLE; SALMON, 2OI5b, p. I82) Isso se reflete em seu trabalho pelo reconhecimento da existência de ações não estritamente guiadas pelo interesse, pelo papel das instituições na fabricação de valores e por uma abordagem genealógica e evolucionista da economia. (CHANTEAU; LABROUSSE, 20I3) Ostrom adota 
uma problemática institucional que detalha as modalidades pelas quais os coletivos estabelecem suas regras práticas, as experimentam, as avaliam e as modificam. (Ostrom, 20Ioa) Isso mostra concretamente que essas formas de auto-organização se revelam mais pertinentes para a governança dos bens comuns do que os procedimentos de mercado ou de Estado.

A economia social rejeita a abordagem residual sugerida pelo conceito de terceiro setor. É a vontade dos atores organizados a fim de promover a cooperação por meio da sociedade de ajuda mútua que explica o surgimento da economia social. (DESROCHE, I976; VIENNEY 1994) Os autores observam que os sistemas de proteção social foram iniciados por atores associativos, cooperativos e mutualistas antes de serem assumidos como importantes conquistas no quadro do estado social. A economia social nasce com a vontade de criar organizações não capitalistas capazes de se iniciar no campo econômico. Em paralelo com a teoria dos bens comuns, o ponto forte da economia social é de propor uma reflexão sobre as regras internas dessas organizações. Assim, a regra do voto "um homem - uma voz" inscreveu nos estatutos das organizações da economia social o princípio democrático de seu funcionamento. Embora as organizações da economia social tenham sido capazes de resistir às pressões do mercado durante muito tempo, elas não têm, infelizmente, conseguido transformar o cenário econômico no seu conjunto. Podemos até dizer que a economia de mercado teve a última palavra em conter seu desenvolvimento e depois transformar essas organizações por dentro através do jogo da padronização e profissionalização. Podemos ver assim o quanto a reflexão sobre as regras é decisiva e, em particular, o quanto é importante pensar sobre a articulação das regras internas com as externas. Ostrom abordou esse problema por meio do seu conceito de governança policêntrica. (OSTROM, 20Iob) Esse tipo de governança pressupõe que as ações possam vir de diferentes níveis - local, nacional, internacional -, cada um dos quais sendo produtor de exigências, de regras e de soluções específicas. A governança policêntrica refere-se a um processo de regulação que respeita a diversidade dos processos de ação e não prioriza necessariamente aquele situado no nível mais elevado. 


\section{Economia solidária e novos comuns}

Em um livro coescrito com Hess, Ostrom também abre a questão dos bens comuns informacionais. (HESS; OSTROM, 2006) Os dois autores especificam em particular sob quais condições os softwares livres são bens comuns. Eles observam que, ao contrário dos bens comuns físicos, bens informacionais são construídos sobre bens não rivais. A partir de então, a questão do tamanho dos coletivos se exprime de maneira diferente. Os comuns informacionais supõem novas proteções. É um famoso programador, Richard Stallman, que tem a ideia de trabalhar com um jurista para produzir, em 1989, uma licença pública General Public License (GPL) cuja vocação é proteger as quatro liberdades do software livre: execução, cópia, modificação e distribuição. A GPL garante que os usuários do software possam manter o acesso ao código-fonte, mesmo nas versões modificadas dele. Essa proteção de software livre é chamada copyleft em vez de copyrigth, este último não permitindo proteger o bem comum. Nos anos 2000, essa inovação se estendeu a outras mídias de suporte, como obras científicas e artísticas, sob o qualificatico de bens comuns criativos - creative commons. Percebe-se, assim, se desenhar uma trajetória que parte da improvisação - bricolage - de informática à reinvenção social. (BROCA, 2013)

Na sequência dos bens comuns informacionais, outros bens comuns são identificados e estudados: comuns culturais, de saúde, de vizinhança, globais, de infraestrutura, urbanos... Hess propõe nomear esses diferentes comuns de maneira agrupada sob o termo genérico de "novos comuns". (HESS, 2008) O termo "novos comuns" tem a vantagem de chamar a atenção para suas respectivas especificidades e a necessidade de defini-las. Segundo Hess, a multiplicação do número de novos bens comuns identificados na literatura atesta uma forte expectativa em nossas sociedades de encontrar respostas apropriadas aos fenômenos de globalização, de mercantilização e de privatização. Para Bollier (20I4), trata-se, a rigor, de se libertar dos pressupostos fundamentais da economia de mercado para promover novas categorias epistemológicas de saberes. Para conseguir isso, os bens comuns contam com um conjunto de direitos distribuídos, 
permitindo qualificar e proteger os usos coletivos emergentes que os bens comuns pretendem fazer prevalecer. (ORSI, 20I5)

No seio dos novos comuns, o conceito de bens comuns urbanos torna possível abordar de maneira diversa os espaços preexistentes (EYNAUD; JUAN; MOUREY, 2OI8), sejam esses lugares tão diferentes quanto edifícios, praças, jardins compartilhados, calçadas, áreas turísticas. Se os bens comuns físicos estão bastante focados na conservação de recursos, os bens comuns urbanos são principalmente orientados para o desenvolvimento de novos usos. (CORIAT, 20I5) Assim, as calçadas podem se tornar comuns se deixamos a liberdade aos habitantes de gerenciar com autonomia determinados espaços verdes da rua. Um imóvel privado pode se tornar um bem comum se for adquirido por uma cooperativa de moradores com o objetivo de fugir à pressão do mercado imobiliário e manter dentro dele aluguéis acessíveis. A transição ecológica também pode se tornar um comum urbano, como mostra o exemplo de Totnes, na Inglaterra, que lançou o programa "cidades em transição". (EYNAUD, 20I6) O objetivo das iniciativas desse programa internacional é incentivar os cidadãos de uma cidade, bairro ou vila a se envolver em ações simples e concretas para enfrentar os desafios das mudanças climáticas. Esses exemplos mostram que os bens comuns urbanos podem nascer na cidade em torno de colaborações originais entre instituições e moradores, alguns dos quais podem ter a fisionomia de um novo empreendedorismo coletivo. (AUFRÈRE; EYNAUD; GAUTHIER; VERCHER-CHAPTAL, 2OI9)

O conceito de economia solidária difere da economia social ao inserir a dimensão política desde o início em sua grade de análise. A economia solidária da década de 1970 abalou uma economia social preocupada demais com a respeitabilidade gerencial e a neutralidade ideológica. Essa perspectiva crítica diz respeito principalmente a três pontos: a importância atribuída ao objeto da produção - incluindo seus aspectos de utilidade social e inovação social -; a mobilização de uma pluralidade de princípios econômicos - mercado, redistribuição, mas também reciprocidade e compartilhamento doméstico, para retomar Polanyi -; e finalmente a ênfase colocada sobre a dimensão 
política - argumentando que a igualdade formal garantida nos estatutos deve ser estendida para as instâncias deliberativas internas e pela participação em debates públicos externos, em aliança com outras lutas e movimentos. É assim que as organizações da economia solidária são consideradas - apesar de seu status de direito privado - como organizações envolvidas voluntariamente em formas de ação pública. (LAVILLE; SALMON 2015b) Para isso, duas constatações podem ser feitas. A primeira diz respeito à denúncia do que Polanyi chama de "sofisma economicista", isto é, a redução da economia unicamente a trocas de mercados. Ao propor uma definição substantiva da economia com base em uma diversidade de princípios ou lógicas da troca coexistindo com as lógicas doméstica, de redistribuição e de reciprocidade (POLANYI, 2OII), a economia solidária apresenta um quadro de análise que possibilita tornar visíveis as ações realizadas pelas organizações que a reinvidica. A segunda constatação refere-se a espaços deliberativos necessários para a implementação de uma abordagem democrática. A economia solidária aborda a democracia em seu espaço cidadão e se recusa a limitá-la à análise de instâncias internas às organizações. Como apontam Nyssens e Petrella (2015), a utilidade social geralmente é multidimensional porque é realizada em torno de um projeto relacionado a um modo de organização. Os benefícios coletivos não são "um fenômeno induzido (uma externalidade) pela atividade econômica, mas uma dimensão reivindicada pelos promotores desses". (LAVILLE, NYSSENS 200I) Portanto, o modo de organização democrática de uma associação não é um simples "algo a mais", pois comporta uma utilidade intrínseca. O conceito de espaço público crítico desenvolvido por Habermas possibilita vincular a questão dos espaços deliberativos e a ação das associações. (HABERMAS, 1988) É uma questão de ver como a ação comunicativa pode se desenvolver em torno de um projeto solidário e se expressar em um espaço público de proximidade. (LAVILLE, 20II)

Se traçarmos de volta as raízes históricas da economia solidária aos autores associacionistas do século XIX, é possível dizer que a economia solidária funda seu projeto na democratização da economia. (LAVILLE, 20IO) Numa abordagem 
pragmática, a economia solidária busca preservar a diversidade institucional valorizando formas híbridas. (NYSSENS PETRELLA, 20I5) Nisso ela se aproxima da teoria dos bens comuns. No entanto, a economia solidária tem características próprias. Ela reconhece a diversidade de partes interessadas e valoriza os coletivos de atores heterogêneos. Também reconhece o papel do Estado na defesa do interesse geral e se inscreve nas estratégias de coprodução e cocriação com as autoridades públicas. Por fim, as organizações de economia solidária contam com uma diversidade de financiamentos - público, mercantil e voluntário -, que lhes permite praticar uma hibridação dos seus recursos.

\section{Em direção a uma síntese pluralista}

A teoria dos bens comuns e a economia solidária podem ser consideradas como duas portas de entrada sobre um mesmo objeto. No lado dos bens comuns, três critérios são essenciais (CORIAT, 20I5): recursos, um sistema de repartição de direitos e regras e uma ampla variedade de acordos de governança. Isso coloca a questão da governança no centro da questão dos bens comuns. Do lado da economia solidária, o importante é uma grade de análise para uma outra economia associada à reflexão sobre o pluralismo das formas de ação pública e democracia. A questão da governança é uma questão relativamente recente para a economia solidária, que foi motivada pela necessidade de entender os modos das organizações híbridas de múltiplas partes interessadas. (BORZAGA; DEPREDI, 20I5) Nota-se, desse modo, uma forte capacidade dos comuns de pensar em formas organizadas localmente em torno de recursos compartilhados e formas relacionadas à produção colaborativa - peer to peer - no espaço digital. A economia solidária, por sua vez, dispõe de uma reflexão conceitual mais orientada à ação pública e à dimensão política construída na interação dos atores da sociedade civil com o Estado. Ambas as análises podem se enriquecer. (EYNAUD; SULTAN, 20I4) Para Bauwens (2015), a convergência entre o bem comum e a economia solidária é forte. Ela pode ser expressa através da criação de cooperativas globais e abertas, fundadas em um novo modelo de propriedade e uma governança de múltiplas partes interessadas. O objetivo 
dessas cooperativas é coproduzir bens comuns. (BAUWENS, 20I5, BAUWENS; LIEVENS, 2016)

Ao excluir o Estado de sua grade de análise como ator da governança, Ostrom precisou do conceito de governança policêntrica para conectar o local ao global. (OSTROM, 2OIob) No entanto, o objetivo da governança policêntrica é principalmente garantir os acordos feitos pelos atores locais. (NYSSENS, PETRELLA, 2015) Para Ostrom, a construção dos bens comuns se impõe sob certas condições específicas e para determinados bens específicos. Sua análise não questiona a racionalidade dos mercados ou do estado. Dardot e Laval (20I4) salientam que um sistema de normas é sempre objeto de conflitos e que a lei é, nesse sentido, um espaço de luta. Dardot e Laval consideram que Ostrom não pensa "na possível constituição política do comum como racionalidade alternativa generalizável". Segundo eles, Ostrom ignora como poderíamos passar dos comuns ao comum. Essas oposições conceituais colocam desafios em cada escola de pensamento e mais além, quando se trata de conectar diferentes escolas.

\section{EPISTEMOLOGIAS E METODOLOGIAS PARA UMA OUTRA GESTÃO}

Se a gestão social e a gestão dos comuns são dois campos diferentes de prática e conhecimento, eles nos parecem, contudo, complementares. Eles são complementares, antes de tudo, por suas origens. O primeiro se inicia efetivamente no estudo das solidariedades entre os humanos, enquanto o segundo está interessado, em primeira análise, nas solidariedades entre os humanos e a natureza. Se seguirmos Polanyi para caracterizar a economia substantiva pela "dependência manifesta do homem em relação à natureza e em relação aos seus semelhantes para obter sua subsistência" (POLANYI, 2OII, p. 56-58), os dois quadros de análises se conjugam para compor os fundamentos de uma gestão substantiva. Em seguida, eles são também cobinados em função das orientações tomadas em suas pesquisas: a gestão social mergulha na questão da solidariedade democrática enquanto a gestão dos bens comuns 
se interessa pela diversidade institucional de formas auto-organizadas. As duas abordagens se completam então para nos ajudar a repensar a emancipação em contextos organizacionais renovados, como aqueles abertos pela paraeconomia de Guerreiro Ramos. Mas essas duas abordagens não são apenas complementares. Nos parece que elas convergem em muitos aspectos e que pontes podem ser construídas entre elas. Essa possibilidade existe principalmente na reflexão em torno de uma postura epistemológica comum e no compartilhamento de metodologias.

\section{Epistemologia para uma outra gestão}

A solidariedade é um conceito flexível que tem a particularidade de poder se casar com muitas disciplinas e escolas de pensamento. (MUSSO, 20I5) Nesse sentido, trata-se de um conceito que faz muito apelo às ciências da gestão na sua interdisplinaridade. Como vimos antes, a solidariedade e a organização estão, cada uma do seu lado, lidando com a história, a antropologia, a sociologia, a psicologia. Tomados em conjunto e em seu caráter transdisciplinar, esses dois conceitos nos levam a requestionar a economia formal e a vislumbrar sua ampliação em direção à economia substantiva. A partir desse alargamento, pode surgir uma postura diferente, susceptível de revisibilizar a contribuição das organizações solidárias e melhorar a compreensão que temos.

O primeiro fundamento dessa postura é político. Ele se expressa na recusa de qualquer tipo de setorização de organizações solidárias. Ao enfatizar o vínculo sobre o bem, a cidadania sobre o consumo, a economia solidária é "uma dinâmica militante e não um setor econômico". (DACHEUX, GOUJON, 2016, p. 203) Podemos deduzir desse primeiro fundamento que todas as organizações podem se apropriar da questão da solidariedade para se transformar em atores na transição ecológica e social. Para tanto, não existem pré-requisitos em termos de atividade, mesmo que a lógica do engajamento possa parecer mais fácil em alguns setores do que em outros. 
O segundo fundamento reside na dimensão pública dessa postura. As iniciativas solidárias têm essa capacidade de servir ao interesse geral. É por isso que eles buscam promover e incentivar espaços de intercâmbio e de palavras que possam ser definidos como espaços públicos de proximidade. (EME; LAVILLE, 1994) Esses espaços são os lugares onde podem se discutir as dimensões da ação solidária participando da ação pública. (LAVILLE; SALMON, 2OI5a) Numa lógica de múltiplas partes interessadas, eles participam do estabelecimento de uma democracia participativa e do fortalecimento da solidariedade em um processo de coconstrução e codecisão. A gestão solidária pode, assim, iniciar um modelo de organização inerentemente democrático, no qual se trata de "reconciliar o cidadão, o empregado e o consumidor" para se engajar no "deliberalismo". (DACHEUX, GOUJON, 2016, p. 204) Em outras palavras, trata-se de - por trás do jogo de palavras - construir um modelo de organização se demarcando dos postulados do liberalismo sem, de todo modo, deixar a esse último à exclusividade de uma reivindicação de liberdade.

O terceiro fundamento é a afirmação pragmática de uma inscrição na ação. Trata-se de trabalhar com pessoas comuns para "moldar suas práticas e desejos" e ampliar o escopo das competências comumente aceitas para romper com uma lógica assistencialista. (FRERE, 2015, p. 390) Com Dewey e contra Lippman, é uma questão de se opor à figura do especialista que se coloca acima dos outros. Essa postura é acompanhada pela rejeição de uma visão dualista do mundo. Ela se opõe "à ambição de construir ciências da sociedade importando os métodos que foram comprovados nas ciências naturais". (GÉNARD, 20I5, p. 55) Trata-se, ao contrário, de privilegiar a preocupação pela compreensão do sentido, caro à Dilthey, contra a visão causal do mundo oriunda das ciências da natureza e o "grande compartilhamento entre natureza e cultura". (GENARD, 20I5, p. 55) Por trás dessas escolhas, o desafio é "evoluir em direção a uma sociologia capaz de progredir, na contingência social, em direção a uma nova política de emancipação que não prescreva nenhum fim predeterminado para as pessoas que tentam se engajar". (FRERE, 2015, p. 356) Tendo em conta os efeitos devastadores sobre a sociedade da mercantilização 
do trabalho, da moeda e da natureza, Burawoy apela aos sociólogos para "cooperar diretamente com a sociedade antes de seu desaparecimento completo" em uma abordagem de "sociologia pública". (BURAWOY, 2013, p. 90-IO2) Parece-nos que nada impede que essa ideia seja estendida à disciplina das ciências da gestão. Os gestores podem efetivamente iniciar uma gestão à vocação pública "instaurando uma colaboração estreita e direta" com as associações, os movimentos e os públicos". (BURAWOY, 2013, p. 90-IO2) Diante das ameaças decorrentes das ondas de mercantilização, uma tal gestão pode se engajar com os atores da sociedade para promover um processo reflexivo de reintegração. Nessa configuração, a ciência social "não se limita à mera empatia", mas "se posiciona nas lutas conduzidas pelos seus atores". (LAVILLE, 20I5, p. 426)

Diante desses postulados de primado do político, da dimensão pública e do pragmatismo, a epistemologia do sul de Sousa Santos aparece como um quadro reflexivo particularmente adequado. Partindo da observação de que o mundo é distorcido pelas relações de dominação, ele propõe um descentramento do pensamento para engajar uma outra relação com o mundo. Como bem recorda Sousa Santos, "a compreensão do mundo excede em muito a compreensão ocidental do mundo". (SOUSA SANTOS, 20I6, p. 24I) A epistemologia do sul proposta por Sousa Santos se dedica à "desconstruir a pretensão de universalidade do etnocentrismo e a negação de certas partes da realidade dela resultante". (LAVILLE, 2015) Ela constata que houve um roubo da história pelo Ocidente. (GOODY, 20IO) Mas o interesse da proposição é que ela não busca substituir um sistema de pensamento monológico por outro, mas, sobretudo, "promover uma conversação com várias vozes". (LAVILLE, 2015) Assim, Sousa Santos nos convida a buscar "uma nova articulação entre os princípios de igualdade e de diferença”. (SOUSA SANTOS, 20I6, p. 260) Para isso, ele coloca a hipótese da "existência de diferenças iguais", autorizando uma "ecologia das diferenças, compreendendo o reconhecimento mútuo". (SOUSA SANTOS, 20I6, p. 260) A epistemologia do sul não deve então ser compreendida numa oposição entre o norte e o sul em uma abordagem que seria apenas geográfica. A epistemologia do sul postula que existe um sul no norte 
e um norte no sul. É, portanto, um diálogo entre as partes visível e invisível de nossos mundos que essa epistemologia nos convida.

Na perspectiva crítica de Bloch (1976), Sousa Santos rejeita os conceitos de "tudo" e de "nada" em proveito da categoria do possível, único capaz de revelar a inesgotabilidade do mundo. Para ele, "o ainda não é uma maneira de registrar o futuro no presente e ampliar o presente". (SOUSA SANTOS, 2016, p. 267) De fato, o "ainda não" de Sousa Santos contém e revela, ao mesmo tempo, um potencial e um poder. A partir dessa ideia inicial, ele deduz dois tipos de sociologia que escapam a uma lógica de determinação e buscam implementar uma "axiologia do cuidar": a sociologia das ausências e a sociologia das emergências. Assim fazendo, Sousa Santos aponta duas direções de trabalho particularmente ricas pois abertas sobre uma recomposição do tempo. Com Guerreiro Ramos, ele se opõe à "monocultura do tempo linear". (SOUSA SANTOS, 20I6, p. 257) Para ele, a pluralidade de tempos é uma condição para entender o mundo porque "a linguagem silenciosa das culturas é acima de tudo uma linguagem temporal". (SOUSA SANTOS, 2016, p. 258) Sua proposição é simples: "Para estender o presente, precisamos de uma sociologia das ausências; para contratar o futuro, uma sociologia das emergências". (SOUSA SANTOS, 20I6, p. 24I) Detalhemos agora essas proposições.

A sociologia das ausências é baseada na observação de que "o que não existe é realmente produzido ativamente como inexistente". Assim, o inexistente é ignorado ou pensado como "uma alternativa não crível àquilo que é suposto existir". (SOUSA SANTOS, 2OII, p. 34) O inexistente é, então, "considerado retrógrado, inferior, local e particular, improdutivo e estéril". (LAVILLE, 2015, p. 427) Em nível metodológico, o objetivo da sociologia das ausências é "libertar as práticas sociais de seu status de resíduo, transferir sua própria temporalidade e, dessa maneira, abrir a possibilidade de desenvolvimento autônomo". (SOUSA SANTOS, 20I6, p. 259) Assim, a sociologia das ausências tem o poder de jogar com as temporalidades, para que "as práticas e sociabilidades se tornem objetos de argumentação e debate político críveis e inteligíveis". (SOUSA SANTOS, 20I6, p. 259) Recorrendo a metáfora da pessoa que perdeu as 
chaves à noite, Sousa Santos nos convida a procurar o molho de chaves ausente não diretamente sob a claridade da lâmpada, mas a nos aventurar nas áreas escuras para onde, justamente, as chaves escorregaram. Esse primeiro esforço é uma precaução indispensável para escapar da armadilha epistemológica de um mundo marcado por uma lógica hegemônica.

A sociologia das emergências, por sua vez, consiste em "substituir o caráter vazio do futuro por um futuro de possibilidades plurais e concretas, utópicas e realistas ao mesmo tempo, e construídas no presente por meio das atividades do cuidar". (SOUSA SANTOS, 2016, p. 266) A sociologia das emergências, portanto, propõe romper as amarras do tempo linear. Ela permite estender o presente "acrescentando à realidade existente as possibilidades futuras e as esperanças que essas possibilidades despertam". (LAVILLE, 2015, p. 427) Essa sociologia ambiciona fortalecer o caráter emancipatório das experiências, a fim de consolidar sua visibilidade e credibilidade. Na recusa de uma simples análise crítica, ela busca reforçar as iniciativas em vez de enfraquecer as bases. (FRÈRE, 2OI5) Por isso, ela se recusa a pensar que os praticantes são abusados pelas normas. De qualquer forma, não deduz uma incapacidade de se engajar na resistência social. (LAVILLE; SALMON, 2015a) Ela abre um espaço de diálogo e de ação com os praticantes, num processo de democracia radical e de enquete social (DEWEY, 1967), em que o pesquisador e o praticante estão em pé de igualdade para compreender e resolver os problemas da ação coletiva.

A epistemologia do sul é particularmente adaptada ao estudo das organizações solidárias. Ela nos ajuda a descentrar o olhar e ir buscar no sul a renovação do pensamento organizacional. Ao cruzar as literaturas brasileira e francesa, este livro contribui para essa ambição. Além disso, Sousa Santos nos convida a trabalhar em um tempo não linear. Este estudo permite revelar que o imaginário associacionista da economia solidária finca suas raízes nos movimentos e pensamentos revolucionários libertários de meados do século XIX. (CEFAÏ, CHANIAL, 2000; CHANIAL 2OIO; FRÈRE, 2009) Esses movimentos, que se demarcaram tanto da economia de mercado quanto da ditadura do proletariado, eram portadores de verdadeiras alternativas à organização 
social. Mas, o associativismo pioneiro foi desprezado por autores liberais e marxistas. No entanto, há uma grande diferença entre a imagem da qual ele foi enfeitado e o conteúdo real de suas ideias. ${ }^{1}$

Se considerarmos esse movimento pioneiro como parte de uma análise crítica, descobriremos ideias que não perderam força. O associacionismo se esforça para prolongar a democracia política na vida social e, portanto, vai contra qualquer separação entre política e economia. (LAVILLE, 20I8) Como observa Abensour, o impulso é fundamentalmente democrático e a utopia é uma condição para a emancipação. (ABENSOUR, 20I3) Esse primado da democracia torna possível defender uma igualdade de direitos e uma lógica de ajuda mútua em oposição à lógica da caridade e da benevolência. A reivindicação é aquela da reciprocidade. Há neste projeto uma intenção de transformação social. Numa abordagem temporal não linear, podemos pensar que a economia solidária contemporânea - com experiências como moedas sociais, serviços de proximidade, circuitos curtos, comércio justo... - é menos uma emergência do que uma ressurgência. (LAVILLE; SALMON, 2015a) A sociologia das ausências nos ajuda a perceber que não apenas as ideias, mas também as realizações são ignoradas. Assim, a revolução francesa é amputada da memória do seu momento solidário. As obras dos historiadores contemporâneos convergem para revelar o esquecimento da revolução de I848 (CHANIAL 2003; GRIBAUDI, 2OI4; HAYAT, 2OI4; RIOT-SARCEY; GRIBAUDI, 2008; RIOT-SARCEY, 2016), que é o das associações solidárias.

Em resumo, as duas abordagens da epistemologia do sul se completam. A sociologia das ausências nos convida a retornar à história esquecida da solidariedade organizacional e a redescobrir as histórias esquecidas que nos ajudam a reajustar nossa visão no presente. A epistemologia das emergências defende, por sua vez, uma valorização das experiências atuais e articula-se perfeitamente com uma abordagem de sociologia ou de gestão pública. Ao fazê-lo, uma reflexão sobre as metodologias mobilizáveis pode se abrir.

1 Ver a esse respeito o número especial de La Revue du M.A.U.S.S., L'autre socialisme, entre utilitarisme et totalitarisme, Paris, La Découverte, second semestre 2000. 


\section{O aporte da antropologia para a outra gestão}

O trabalho em gestão solidária mobiliza um amplo repertório de conhecimentos e de disciplinas científicas. A inscrição da gestão nas ciências sociais é um princípio forte para reafirmar o projeto de uma outra gestão que se propõe explorar a diversidade de significados associados às práticas. A reflexividade é um exercício constante dessa outra maneira de fazer a gestão. Nesse campo, a contribuição da antropologia é particularmente importante não apenas em termos de reflexão, mas também para orientar as práticas de uma outra gestão. O conhecimento em antropologia é construído como uma ciência da alteridade com a ambição de entender o outro - a outra sociedade, a outra cultura.

Para os antropólogos, o conhecimento é construído pela compreensão e pelo reconhecimento de uma diferença. Portanto, é menos uma questão de definir um objeto de pesquisa do que um método. A antropologia é moldada por sua maneira de apreender a realidade e sua capacidade de imersão no campo, como mostra a prática etnográfica. A formação em antropologia consiste em exercitar um outro olhar sobre o mundo. A experiência desse exercício é revelada como uma vivência intercultural. O esforço de percepção do outro em sua diferença produz um efeito reflexivo na direção de si mesmo, da sua cultura e da sua sociedade. Segundo Laplantine e Olievenstein (I993), a perplexidade ou "sensação de estranheza" que nasce do encontro de culturas é inerente à formação antropológica. Isso leva a modificação do olhar sobre si mesmo. O trabalho de campo induz transformações pessoais que vão muito além do escopo de uma prática profissional ou de um projeto de formação científica, desencadeando um processo de aprendizagem existencial.

\section{Da outra gestão à gestão do outro}

Definimos a outra gestão como uma gestão diferente por seus métodos, princípios e racionalidade. A contribuição da antropologia nos permitiu especificar essa definição. A outra gestão é uma gestão da diferença. Ao fazê-lo, ela afirma uma dimensão política no sentido de Arendt, com a consideração 
dos homens e não do homem. (ARENDT, 1994) É, portanto, uma gestão que se expressa com e na alteridade. Nesse sentido, a questão do reconhecimento ocupa um lugar central. A outra gestão leva em consideração a busca de reconhecimento ao propor: outra institucionalidade econômica - para além da economia de mercado -, outras formas de organização - para além do princípio de empresas -, outros territórios - para além dos espaços urbanos comerciais -, outros públicos - para além daqueles já cobertos. Assim, ela se situa no reconhecimento de outra cultura do viver em sociedade - para além do individualismo. Ela busca o que não é claramente visível, o que o cotidiano invisibiliza, o que emerge. Nesse sentido, a abordagem antropológica anda de mãos dadas com a dupla perspectiva sociológica proposta pela epistemologia do sul. (SOUSA SANTOS, 20I6) É necessário para a outra gestão assumir o desafio da diversidade e do diálogo intercultural. Nessa perspectiva, a epistemologia do sul pode ser relevante, pois renuncia ao monopólio das visões dominantes da modernidade ocidental, para integrar versões subalternas e reduzidas ao silêncio. (SOUSA SANTOS, 20I6)

De fato, em se tratando do tema da interculturalidade, importa salientar que a questão do reconhecimento está no coração da problemática da relação com a diferença, na qual as sociedades humanas sempre estiveram confrontadas. Historicamente, duas formas prevaleceram no modo pelo qual as sociedades trataram a diferença, segundo Todorov (I993): de um lado, a hierarquização, levando à uma relação de subordinação através da inferiorização de certos grupos sociais; e, do outro, a assimilação, levando a dissolução do problema, numa espécie de negação pela simples extirpação da questão. Contudo, uma boa parte das sociedades contemporâneas se colocam como tarefa fundamental o desafio de conservar a diferença sem perder a coesão social, ou seja, gerir a diferença sem pretender neutralizá-la ou dissolvê-la. (BARBOSA, VELOSO, 2009) É assim que o problema do reconhecimento se torna um tópico central no debate sobre o multiculturalismo. Aparecido em meados da década de I970, o conceito pretendia fornecer chaves de ação para governos de países como Canadá e Austrália, para definir políticas adaptadas 
às minorias culturais e ao pluralismo étnico que caracterizam essas sociedades. (BARBOSA, VELOSO, 2009) O objetivo era a superação de políticas assimilacionistas, consideradas moralmente duvidosas. Nesse intuito, tratava-se de optar pela manutenção das identidades culturais das minorias e favorecer, ao mesmo tempo, o sentimento de orgulho pelas diferenças culturais e o sentimento de pertencimento a um grupo maior. Como doutrina política, o multiculturalismo apoiou políticas para o reconhecimento dos direitos e identidades culturais das minorias e defendeu a diversidade cultural. (BARBOSA, VELOSO, 2009)

Inúmeros estudos sobre esse assunto, desde o início dos anos 2000, ajudaram a evolução do pensamento multicultural (BARBOSA, VELOSO, 2009), revelando duas perspectivas diferentes. A primeira é apoiada por Charles Taylor (1992) e Will Kymlicka (1997), que argumentam que a diferença é o valor intrínseco de uma sociedade multicultural. Para eles, a diferença pressupõe seu reconhecimento sem a exigência de sua superação pela construção de um mundo comum. "Reconhecer" significa aceitar a existência do outro sem compromisso. Sínteses são então produzidas entre as diferenças. A segunda perspectiva é apoiada por autores como Fraser (FRASER; HONNETH, 2003) e Honneth (HONNETH; JOEL, 1998, 2003). Eles consideram que o reconhecimento da existência de uma diferença é insuficiente se a sociedade não souber como tratá-la. (BARBOSA; VELOSO, 2009) Em Fraser (1998), a dificuldade da relação ao outro remete a um dilema profundo: como oferecer reconhecimento sem redistribuição de recursos e sem justiça social? Para Honneth (1998), trata-se de reunir em torno da noção de reconhecimento tanto os aspectos culturais valorizados por Taylor (I992) e Kymlicka (1997) quanto um imperativo moral e ético, permitindo um maior nível de consenso e de unidade. (BARBOSA; VELOSO, 2009) A questão posta por Honneth pode ser formulada nos seguintes termos: como oferecer reconhecimento sem estima social? Com esse autor, reconhecer o outro se verifica apenas quando são estabelecidos elos de mediação baseados na solidariedade. (HONNETH, I998) A estima social, para Honneth, refere-se à 
existência de laços morais entre indivíduos social e culturalmente diferentes. Diferentemente de uma simples "aceitação do outro", Honneth sugere "a apreciação do outro", através do estabelecimento de uma sociabilidade baseada na reciprocidade. (BARBOSA; VELOSO, 2009)

\section{Antropologia cultural, econômica e organizacional}

Hoje, mais do que nunca, as sociedades são confrontadas a questão da relação com a diferença. O aumento dos fluxos migratórios ao redor do mundo e conflitos de todos os tipos testemunham a importância do problema. O aumento da desigualdade reforça o difícil exercício da prática do reconhecimento, conforme a interrogação de Fraser salientada antes. Vimos a partir de Honneth que a prática genuína da diversidade cultural pressupõe uma mudança em nossas formas de socialização, que, por sua vez, recoloca a centralidade da solidariedade. Afinal de contas: como oferecer reconhecimento se não cultivamos coletivamente o interesse pelo outro? Como oferecer reconhecimento se não organizarmos coletivamente solidariedades ativas? Ou como oferecer reconhecimento se a solidariedade está ausente? ... e se estamos cada vez mais movidos por modos de sociabilidade individualistas...

Ora, a relação entre uma sociabilidade individualista e uma forma de economia orientada segundo esses mesmos valores parecem evidentes. Da ênfase sobre a importância de uma dimensão econômica de distribuição de recursos - e a agenda de direitos que a acompanha, conforme salienta Fraser - como uma condição fundamental para a efetividade do reconhecimento se acrescenta então o imperativo de um outro olhar sobre o econômico. A questão do reconhecimento e a problemática da diversidade cultural apontam assim uma ligação forte com a reflexão trazida neste livro sobre a outra economia: como oferecer reconhecimento sem uma outra economia? Essas questões enfatizam a importância da inscrição na abordagem abrangente e substantiva de Polanyi e Guerreiro Ramos. Como oferecer reconhecimento sem uma economia solidária? Compreender essa sociabilidade solidária é uma das tarefas importantes que são essenciais para definir os contornos de outra gestão. 
Na busca pelos fundamentos do conhecimento permitindo melhor compreender a sociabilidade solidária na base da outra economia, a antropologia econômica constitui uma fonte privilegiada. Vimos nos capítulos anteriores como um outro olhar sobre a economia - realizado por estudos de história e antropologia - permite melhor enxergar a diversidade dos princípios e modos de instituir a economia em diferentes culturas e sociedades humanas. Ao favorecer então uma maior amplitude do olhar sobre o econômico, a abordagem da antropologia econômica é portadora de respostas e de pistas de reflexão para as questões contemporâneas. Ela abre a análise sobre a história e sobre outras culturas. Pelo descentramento da visão que ela propõe, a antropologia é particularmente útil: o que a história pretérita de outras economias e de outras culturas pode nos permitir aprender sobre os problemas da economia de hoje? O que o passado nos ensina? O que a cultura dos povos ancestrais nos transmite? A antropologia econômica não é a expressão de uma nostalgia ligada aos tempos antigos. É uma fonte privilegiada de inspiração para encontrar, no estudo da diversidade cultural, os novos caminhos da gestão capazes de lidar com os desafios contemporâneos.

Encontrar os fundamentos antropológicos da outra gestão, como vimos, nos obriga a um desvio sobre dois domínios de conhecimento fundamentais que são as temáticas da diversidade cultural através da questão do reconhecimento e a problemática da outra economia. Assim, afirmar o reconhecimento é também um princípio maior da outra economia. Ora, se as exigências da outra economia se abrem sobre a necessidade de uma outra gestão, nosso caminho deve se refazer: de uma abordagem de antropologia cultural passando pela antropologia econômica para retornar sobre a antropologia organizacional propondo-a uma nova agenda.

Articular os conhecimentos da antropologia e da gestão constitui a razão de ser da antropologia organizacional. Sendo seu propósito o de trazer maior amplitude em termos de análise organizacional, isso não ocorre, contudo, sem tensão. É preciso retornar ao olhar inicial sobre a relação entre cultura e gestão através da temática da cultura organizacional desde a primeira metade 
dos anos I980 para reconhecer a origem da formação desse campo da antropologia organizacional. Se pelo viés da cultura no sentido antropológico do termo abriu-se uma perspectiva mais aprofundada de olhar sobre os problemas da gestão, por outro lado, tornou-se frequente a abordagem da cultura como sendo uma variável gerenciável na perspectiva de maior performance econômica através do emprego da noção de cultura de empresa. Foi assim que o tratamento do tema da cultura se prestou a diferentes finalidades, diversas interpretações e foi alvo de intensos debates e discussões, conforme o uso feito por inúmeros pesquisadores, homens de negócios e gestores em geral.

De uma diversidade de tratamento do tema da cultura organizacional num primeiro momento, o campo da antropologia organizacional se desenvolverá em seguida através de vários trabalhos de pesquisa em gestão com o uso do método etnográfico. Algumas etnografias organizacionais apareceram antes mesmo do surgimento do tema da cultura organizacional, contudo, sua disseminação importante ocorrerá sobretudo a partir dos anos I99o. Mas, ainda assim, a etnografia permanecia sendo considerada como um recurso metodológico relativamente marginal nos estudos em gestão ao requerer nível tão elevado de aprofundamento investigativo em termos qualitativos. Com a expansão gradual de tais pesquisas, a antropologia organizacional vai então estender seu inventário de temáticas: etnomarketing, gestão da diversidade, empreendedorismo étnico e gestão intercultural são alguns assuntos que vão se adicionar à cultura organizacional e à pesquisa etnográfica aplicada à gestão.

O que parece importante destacar no projeto de uma antropologia organizacional é o modo como apresenta seu olhar sobre a problemática da gestão, cuja inflexão evita limitar-se apenas às expectativas de performance econômico-financeira. As bases de um tal olhar foram colocadas desde o início conforme salienta o texto seminal de Chanlat (I99I) propondo uma antropologia da condição humana nas organizações. Em sua abordagem, esse autor defende uma tomada de posição distinta sobre o humano nas organizações, para além das perspectivas comporamentalistas. Ao denunciar o caráter restrito da 
formação em gestão, Chanlat (199I) recorre as múltiplas dimensões do humano na base de uma proposta de teoria antropológica das organizações apreendida segundo diversos níveis em interação entre o indivíduo e a sociedade.

\section{A outra gestão e a educação popular}

Reencontrar essa condição humana nas organizações parece ser a contribuição fundamental da antropologia para a outra gestão. As exigências da outra gestão na prática são da ordem da mediação social: entre sujeitos ou entre instituições, pertencentes a diferentes mundos sociais ou não. Isso pressupõe a efetividade do exercício de um outro olhar que se aprende como uma postura antropológica face aos outros, face às instituições, diante da sociedade, diante do mundo e diante da vida. O objetivo da outra gestão sendo o de alcançar as necessidades ou demandas do outro - o indivíduo, o contexto local, a sociedade -, ela então inverte o caráter autocentrado inerente à racionalidade do mercado e seu modo de gestão. Compreender o outro é uma questão intrínseca da outra gestão, pois trata-se de acolher sua demanda, sua necessidade. A outra gestão exige esse movimento de descentramento na direção do outro, por isso é uma experiência com o sensível.

Como experiência do sensível, a outra gestão não se realiza sem uma reflexão da ação (práxis) em torno do sentido do trabalho, do pertencimento a um grupo, da sua relação com a instituição ou com a sociedade. A outra gestão redefine a relação entre os indivíduos e suas organizações ou entre os indivíduos e a sociedade, ela se elabora no entrecruzamento dos projetos pessoais com os projetos coletivos e reposiciona a relação entre indivíduo e sociedade. Dessa forma, ela torna possível recuperar o significado perdido de muitos projetos institucionais que se encontram confrontados as derivas individualistas marcadas pelas carreiras profissionais de pessoas desprovidas de outros referencias e valores além daqueles da realização material. Ampliar os sentidos para os sujeitos é também uma busca de sentido para as instituições na sociedade. Eis uma das vocações da outra gestão. 
Nessa perspectiva, a postura antropológica requerida pela outra gestão não se completa sem uma abordagem de educação. O papel do gestor aqui é confundido com o de educador, no sentido freiriano. A exigência de mediação social na outra gestão traz à tona o imperativo da dialogicidade. Segundo Freire (1994), o processo libertador da educação é realizado em uma relação permanente de alternância de papéis entre aquele que educa e aquele que é educado. Essa alternância se justifica pela necessidade de compreender o mundo do outro, isto é, daquele em processo de educação. Segundo Freire, não podemos construir um processo de aprendizagem sem referência ao contexto ou realidade concreta de vida dos envolvidos. O que permite então essa alternância de papéis é justamente o diálogo entre educador e educando. No sentido contrário, ou seja, no que Freire (1994) designa como "concepção bancária da educação", o diálogo é interditado, da mesma forma que a alternância de papéis entre educador e educando. A aprendizagem é concebida como simples transferência de conhecimento vistas como informações a serem retidas: o professor deve depositar o saber na cabeça do aluno que deve recebê-lo passivamente. Enquanto uma "concepção bancária" funda uma "pedagogia do oprimido", o princípio da dialogicidade está na base de uma "pedagogia da libertação". (FREIRE, 1994) Paulo Freire foi conhecido internacionalmente por seus métodos de alfabetização para jovens e adultos, concebidos como uma práxis política em razão da conscientização mais ampla da realidade favorecida pelo seu processo de aprendizagem. Suas ideias estão na base de muitas abordagens em um campo de conhecimento qualificado como Educação Popular (EP).

Segundo Paludo (20I5), a EP é um campo de conhecimento relacionado às práticas educacionais que participam de um exercício de crítica permanente ao sistema social. A abordagem é contra hegemônica e promove outro modelo de sociabilidade. Resultado de lutas e resistências populares na América Latina, essa concepção vincula estreitamente a educação e a política na busca pela emancipação. No Brasil, a educação popular nasceu dos movimentos de educação de base e da cultura popular do final da década de i950 e cresceu na 
resistência popular das décadas de 1970 a 1980 como um conjunto de ideias ao mesmo tempo políticas, filosóficas e pedagógicas. (GOHN, 20I3, 20I5)

Entre os diferentes paradigmas da educação popular, o método de Freire é um dos mais importantes na América Latina e em outras partes do mundo. (GADOTTI, I999) Surgiu progressivamente como uma alternativa emancipatória aos currículos pré-escolares vigentes na época. Estes últimos foram desenvolvidos desde o final da Segunda Guerra Mundial, patrocinados principalmente por agências norte-americanas e de outros países. Eles consistiam principalmente em programas de extensão rural e desenvolvimento comunitário. Por outro lado, o método de Freire era multidisciplinar e considerou várias dimensões, incluindo a educação política. (GOHN, 20I5)

De fato, Freire postulou uma educação libertadora orientada para a conscientização e transformação dos indivíduos e seu ambiente social. (FREIRE, I979) Vimos antes que uma das grandes inovações do seu método é o fato de basear-se no diálogo, razão pela qual a comunicação torna-se uma questão maior. (FREIRE, 1983) Para Freire, comunicação e reflexividade são grandes desafios em situações de aprendizagem. (FREIRE, I994) Os oprimidos só são livres quando adquirem a capacidade de refletir sobre as condições de suas próprias vidas e conquistam sua autonomia para alcançar seu destino histórico. (GOHN, 20I5) A pedagogia do diálogo redefine a relação pedagógica. Freire vê o professor como alguém que procura e aprende se situando ao lado do estudante. Este último tem uma posição ativa e, assim, ganha construindo sua dignidade no processo educativo. (GOHN, 20I5)

No trabalho de Freire, a educação é uma prática de liberdade que promove a conscientização. (GOHN, 20I5) É também um ato político, um ato de conhecimento e um ato de criação que postula que a realidade deve ser transformada. Para serem libertadores, os educadores devem ter consciência histórica e política. Entendemos que a educação popular desempenhou um papel fundamental nos movimentos de resistência das décadas de 1970 e 1980. Naquela época, na América Latina em geral e no Brasil, em particular, a EP era sinônimo de movimento social. Posteriormente, ela estendeu suas práticas a organizações da sociedade civil, universidades, certas 
autoridades públicas com o objetivo comum de apoiar populações ou grupos sociais marginalizados.

É precisamente esse trabalho de mediação social entre mundos sociais distintos e entre diferentes instituições, cujo objetivo é o fortalecimento de uma solidariedade emancipatória, que funda o campo de uma outra gestão. Os desafios desse trabalho de mediação e suas exigências em matéria de gestão são imensos e traçam uma agenda relevante para o conhecimento e a prática da gestão. Entretanto, uma questão se impõe neste momento: por que esse tipo de trabalho não fora jamais concebido como uma abordagem ou um problema de gestão? Essa questão é explicada, como vimos no capítulo primeiro, através da destituição da solidariedade no campo de constituição das ciências da gestão. De todo modo, eis que nos encontramos novamente neste momento diante de uma outra definição para a outra gestão: trata-se de uma prática de mediação social fundada sobre métodos de educação popular que levam a processos de solidariedade emancipatórios. Ou seja, toda forma de gestão implicando uma abordagem da educação em direção à emancipação nos parece constituir uma outra gestão. Em resumo, fazer a outra gestão é um ato de educação e pressupõe incarnar uma postura antropológica, de um outro olhar da realidade. A postura antropológica tornando-se, então, também uma postura de gestão, estamos diante de uma tomada de posição ética em matéria de gestão. Uma série de princípios e valores devem animar essa postura: confiança, respeito, diálogo, solidariedade, emancipação, alteridade, escuta e mediação social. Diante de uma tal formulação, algumas interrogações se colocam no nível da aplicação do conceito, especialmente, no que diz respeito aos meios, ferramentas, instrumentos ou métodos da outra gestão. o exemplo da etnocontabilidade indica grande pertinência a esse respeito

\section{A etnocontabilidade}

O ponto de partida da etnocontabilidade se encontra, segundo Cottereau (2016), numa interrogação sobre o que conta na vida. Trata-se de uma questão primeira e fundamental pois indica uma ampliação prática e conceitual. 
Ao se perguntar sobre o que conta para as pessoas, a etnocontabilidade recoloca efetivamente o sujeito humano no centro da análise. Aquilo que é mais importante para as pessoas, segundo essa abordagem, é aquilo que conta na (ou para a) vida delas. Nesse sentido, estende-se a abordagem contábil para a questão do bem-estar. A competência da avaliação se desloca então do estatístico ou do economista para o interessado. (COTTEREAU; MOHATAR MAZOK, 2OI2) A ideia força desta abordagem é não separar da análise aquilo que se refere ao econômico daquilo que se refere à vida cotidiana: "Na vida, as pessoas contam e avaliam, e investigar as suas maneiras de operar exige não impôr a priori uma separação entre os fatos de ordem econômica e os de outra ordem". (COTTEREAU, 20I6, p. II) Para este autor, levar em consideração o que as pessoas levam em consideração é um processo semelhante a uma "desintoxicação": libertar-se do homo economicus em proveito de um certo hommo ethicus - diria Walras. Isso põe em cheque a abordagem da separação disciplinar usual, reservando aos economistas a análise modelizadora da relação dos homens com as coisas, de um lado, e (reservando) aos cientistas sociais "o estudo do enraizamento social da vida econômica ou da significação social do dinheiro" (COTTEREAU, 20I6, p. II), do outro, isto é, as relações dos homens a propósito das coisas. Segundo Orléan (20II), essa característica marca a vontade da economia ortodoxa de se demarcar do resto das ciências sociais. Assim, a economia ortodoxa pensa ser possível obter uma medida objetiva de valor, enquanto a antropologia, a história e a sociologia remetem a interação entre os homens e a intersubjetividade.

Segundo Orléan, essa crise tem origem no fato de que "deixamos a avaliação nas mãos do mercado, enquanto que os mercados praticam uma forma patológica de avaliação”. (ORLÉAN, 2OI2, p. 2I) Essa patologia se expressa através da confusão entre medida e avaliação. Conforme lembra Supiot, "confundir a medida e a avaliação condena a perda de sentido da medida". (SUPIOT, 20Io, p. 82) De fato, avaliar não é somente medir ou mensurar, "mas remeter à medida à um julgamento de valor que a confere um sentido". (SUPIOT, 2OIO, p. 82) Confundir medida e avaliação leva a esmagar os diferentes julgamentos que estão presentes nas relações. No caso de um pequeno comerciante de 
bairro, por exemplo, são muitos e variados os julgamentos que este pode fazer da pessoa que está diante de si, sobre sua capacidade de pagar. São relações mais humanas que podem se estabelecer, relações que enxergam no preço outras coisas além simplesmente do ganho que se pode auferir, ou seja, que leva em conta as condições da pessoa. (COTTEREAU, 20I6) Quando medida e avaliação se superpõem, apenas os preços ficam visíveis. A parte social em jogo na troca mercantil que teria conduzido a modificar o preço é apagada. Assim, a eventual gratuidade da troca desaparece, assim como "as avaliações que levaram a fazer um preço de presente". (COTTEREAU, 20I6)

Doravante, refundar a economia pressupõe um trabalho sobre o modo de abordagem do valor a fim de reencontrar sua natureza relacional. Para tanto, a etnocontabilidade se propõe a contar como as pessoas contam. Num plano prático, a etnocontabilidade consiste num "dispositivo de investigação destinado a tornar visível a economia dita 'invisível'". (COTTEREAU, 20ı6, p. I7) Contudo, é necessário precisar que essa "invisibilidade" não é total. A economia doméstica salientada por Polanyi é antes de tudo invisível "aos olhos das instituições, dos dispositivos oficiais de registro privados e públicos". (COTTEREAU, 20i6) Ao qualificá-las como economia "informal" estas mesmas instituições as mantém numa invisibilidade assumida que supõe um certo descrédito. Todo o trabalho da etnocontabilidade consiste então em descrever o que não está descrito, em prestar conta das formas muito precisas assumidas por essa economia supostamente informal, a atribuindo consistência e realidade. Para isso, o trabalho de valorização visa "tratar as famílias como produtores", e a analisar "toda atividade de fabricação ou de serviço permitindo entrada de recursos". (COTTEREAU, 20I6, p. 2I) A etnocontabilidade busca "levar a sério a arte da gestão dos indivíduos e das unidades familiares" (COTTEREAU, 20I6, p. 23), carregando tanta atenção no "governo autônomo das condutas de vida" quanto na "governança das empresas e outras coletividades". (COTTEREAU, 20I6, p. 23) Fica claro então que este trabalho participa de uma sociologia das ausências. 
No plano metodológico, a pesquisa etnocontábil implica "restituir a avaliação que cada um faz dos seus recursos através de uma etnografia do cotidiano, no seu dia-a-dia, e uma coleção de arquivos pessoais coletados no lugar, registrados num diário de pesquisa extensa". (PRUVOST, 2016, p. I05-I06) Trata-se, em seguida, de "formalizar as avaliações estimadas pelos atores sobre o alto valor de elementos da sua vida ou da sua incomensurabilidade, sintetizando as informações em quadros contábeis, de uso do tempo ou de inventários, submetidos às enquetes para correção". (PRUVOST, 20I6, p. I05-IO6) Não se trata de "converter o conjunto das trocas em equivalentes monetários ou em cálculos lucrativos, mas de observar os procedimentos de avaliação ordinários, indissociáveis de arbitragens mais amplas sobre o que é uma boa vida no plano familiar, de amizade, militante e profissional". (PRUVOST, 2016, p.IO6)

A etnocontabilidade se define como uma "antropologia da avaliação ou uma contabilidade contextual”. (BLAVIER, 20I6, p. 28) Seu procedimento consiste num trabalho minucioso de contar a partir das enquetes de todas as trocas socioeconômicas realizados no seio de um casal ou da família. Nesse sentido, o trabalho do etnocontador - ou etnocontabilista - mistura a abordagem etnográfica qualitativa usual com as medidas quantitativas objetivas para se aproximar de um "balanço específico do bem-estar". (COTTEREAU; MOHATAR MARZOT, 20I2, p.I7) Isso permite estudar as solidariedades intra e interfamiliares que são negligenciadas pelas estatísticas oficiais. A abordagem etnocontábil mostra que a compra de um bem não é suficiente para se inserir "localmente numa cadeia de solidariedade benevolente (municipal, local, alternativa, familiar)" e que é preciso também contar com "uma integração paciente em diferentes redes de ajuda mútua”. (PRUVOST, 20I6, p. II8) Conforme a orientação trazida pela sociologia das ausências, a etnocontabilidade deseja expor o invisível das relações sociais que fundam e organizam a economia doméstica. No mesmo espírito, a etnocontabilidade dedica especial atenção a vida dos mais pobres e dos mais destituídos. (MACCHI, 2OI6; LE MÉNER, 20I6) 
Esse trabalho rigoroso de análise permite escapar das abordagens "miserabilistas", ao salientar o rigor da gestão em tais famílias diante das enormes restrições próprias à sua realidade. Além disso, este trabalho indica critérios de intervenção possíveis no quadro das políticas públicas e aponta novos elementos para uma melhor compreensão da arte de viver em conjunto. (GUÉNÉE, 20I6, p. IO2) Enfim, esta abordagem nos abre perspectivas para a coconstrução de indicadores de bem-estar e sua discussão "entre cidadãos muito diversos que não compartilham os mesmos gostos nem a mesma visão de mundo e nem possuem os mesmos interesses. Para além dos indicadores em si, esse processo de comunicação permite também tecer os vínculos entre cidadãos que não encontram tantas ocasiões para dialogarem ou para se encontrar". (RENAULT, 20II, p. I68-I69) A questão em seguida é de saber sobre como utilizar estes indicadores.

\section{Os instrumentos e as ferramentas da outra gestão}

Como vimos anteriormente, a história do pensamento em gestão é marcada por sua dimensão aplicada. Esses conceitos têm um objetivo prático. Eles buscam abordar os problemas concretos das organizações e apoiar a formulação e o design de ferramentas de gerenciamento. O foco na empresa privada de mercado como objeto primeiro - e quase único - de análise é, sem dúvida, um fator de empobrecimento. Assim, a gestão parece conhecer apenas o universo de empresas que obedecem à lógica do mercado. O ensino de administração difunde um "pensamento gerencial" banhado em preocupações econômico-financeiras e iluminado por um Graal: o desempenho. Esse Graal é o objeto de todas as atenções. A ambição do gestor é dominar todas as características da performance e servi-la piedosamente por meio de um aparato de tecnologias gerenciais. (FRANÇA FILHO, 2003) Se qualquer ação pode ser instrumentalizada, ela não é, contudo, menos guiada por princípios. A visão formal e funcionalista que a administração cultiva tende, em todo caso, a obscurecer esses valores. Enquanto produtores da medida, as ferramentas de gestão participam de um trabalho de justificação. (BOLTANSKY; THÉVENOT, I99I). O uso de ferramentas de gerenciamento de desempenho financeiro em 
uma organização é uma garantia de racionalidade formal. Essa garantia se faz em detrimento de uma racionalidade de valor, como foi claramente demonstrado por Guerreiro Ramos.

Essa situação é claramente prejudicial para organizações que têm necessidades de gerenciamento, mas cuja racionalidade não é a mesma que racionalidade de mercado. Naturalmente, pensamos em organizações públicas, associações, cooperativas, organizações mutualistas, fundações, mas também empresas familiares e empresas que desejam se afastar dessa racionalidade, como é o caso das empresas liberadas ou entreprises libérées. (GILBERT; TEGLBORG; RAULET-CROSET, 20I7) Todas essas organizações muito diversas em suas estruturas e propósitos ficam órfãs de uma gestão que possa responder à sua diferença e à sua especificidade. A situação é grave pois a extensão do pensamento gerencial corporativo a todas essas organizações tende a ser valorizada como um progresso geral. (EYNAUD; MOUREY, 2015) Seguindo então esse modo de raciocinar, acredita-se que introduzir o gerenciamento de negócios com sua lógica de margem de lucro nos hospitais públicos responsáveis por nossa saúde seria bom para o interesse geral. Assim como se pensa que a racionalização dos custos por uma associação de solidariedade que lida com os mais pobres participaria da profissionalização de sua gestão. (EYNAUD; MOUREY, 20I2) E acredita-se também que filiar associações sociais de bairro em uma associação de pais de tamanho regional ajudaria a melhorar o serviço aos usuários, ou que corrigir as finanças de um centro social como se apura as contas de uma empresa superendividada seria uma vantagem para os beneficiários. Tais exemplos podem ser multiplicados facilmente, importa, contudo, salientar que tais situações chocam muito poucas pessoas. O homo economicus adquire precedência sobre o homo ethhicus. Parecemos perplexos coletivamente e a monocultura da gestão de negócios dificilmente é denunciada. A observação de Bonnafous-Boucher (2005) sobre a necessidade de teorias da organização em vez de uma teoria das organizações permanece uma letra morta, pelo menos no ensino da administração. As razões para essa falta 
de consideração são, sem dúvida, encontradas na análise de Sousa Santos sobre a sociologia das ausências.

O campo do conhecimento em gestão deixou em aberto um oceano de possibilidades para a proposição de uma outra gestão. Um fator positivo é o crescimento da literatura crítica no campo da administração e gestão. (DORION, 2OI7) Essa literatura particularmente estimulante revela avanços consideráveis no diagnóstico da realidade. No entanto, parece-nos que ainda falta fazer uma agenda de pesquisa sobre outra gestão. Essa agenda deve interagir com uma ampla variedade de questões fundamentais que emergem da dinâmica complexa das sociedades contemporâneas. Portanto, é necessário aprofundar o pensamento, enriquecendo-o com contribuições dos mais diversos campos das ciências humanas e sociais. Mais do que a gestão formal, a gestão substantiva tem uma necessidade crucial de desenvolver abordagens interdisciplinares. Elas são realmente as únicas capazes de apreender em sua complexidade os riscos da ação coletiva quando esta não se confunde com o mercado. O destaque desta agenda é a possibilidade de combinar conhecimento teórico em gestão com o que é inventado todos os dias no campo de ação dessas organizações. Embora seu gerenciamento não seja o mesmo que o gerenciamento de uma empresa mercantil, essas organizações também precisam de instrumentos para análise, gerenciamento e tomada de decisão. Portanto, podemos nos perguntar: Que tipos de tecnologias a outra gestão precisa? Como é definido o método da outra gestão? Como se faz a gestão da outra economia? Que ferramentas são necessárias para construir na prática a gestão da desmercadorização do trabalho, da moeda e da natureza? Pela sua diversidade, essas questões de ordem geral indicam o escopo mais amplo dessa agenda. Na perspectiva da outra gestão, dois aspectos aparecem como primordiais: levar em conta o contexto específico em que as organizações agem e interagem e confrontar regularmente as realidades em campo. O desafio para a outra gestão é certamente poder articular o particular e o geral e ter ferramentas cujos contornos se casem com essa necessidade de articulação. 
A prática de incubação em economia solidária é particularmente interessante, pois combina um espaço para pesquisa e um espaço para experimentação. Nesse sentido, é um campo de trabalho ideal para a construção de ferramentas adaptadas às necessidades da outra gestão. O trabalho realizado sobre essas práticas de solidariedade permite destacar três categorias principais de ferramentas: a) ferramentas de gestão para cada iniciativa (intraferramenta); b) ferramentas de gestão de redes de solidariedade à qual a iniciativa pertence (interintra ferramenta); c) ferramentas de gestão da relação com atores institucionais distintos (interferramentas). Qualquer que seja a categoria, as ferramentas da outra gestão precisam ser mais exigentes do que as ferramentas convencionais de gestão de negócios. De fato, espera-se que sejam coerentes com valores como solidariedade, cooperação e confiança. Para alcançar essa coerência, duas pistas - já evocadas - podem ser seguidas. A primeira remete a uma abordagem de inovação social que pode orientar o coletivo. A segunda é um trabalho de ressignificação da relação entre ciência, tecnologia e inovação. Nesses casos, até mesmo a construção das ferramentas em si já representa um processo de inovação de natureza diferente - como vimos no capítulo anterior. Esse é um campo promissor de pesquisa aplicado às ciências da gestão, que se abre a questões como: Quais ferramentas são socialmente apropriadas às realidades das organizações que procuram transformar seu ambiente? Como construir essas ferramentas? Como elas são capazes de redefinir a relação entre ciência, tecnologia e inovação? Como integrá-las a uma abordagem transdisciplinar do conhecimento relacionada a uma "ecologia de saberes"? (SOUSA SANTOS, 2016)

\section{Da viabilidade financeira à utilidade social}

O contexto brasileiro é particularmente emblemático porque se beneficia de uma importante experiência de intervenção solidária em territórios altamente desfavorecidos. O principal desafio de trabalhar com pessoas excluídas é entender seus percursos e os déficits acumulados. Esse é um pré-requisito antes de pensar em qualquer reintegração. Parece difícil prever um 
projeto de reintegração de pessoas altamente excluídas apenas com base no critério de viabilidade financeira. De fato, as iniciativas de economia solidária respondem a fortes demandas em termos de necessidades locais e são de grande importância na vida das pessoas. Os resultados obtidos por essas iniciativas devem ser avaliados em um perímetro mais largo, para entender o que mudou na vida das pessoas envolvidas - aqueles que participam diretamente das iniciativas, mas também os beneficiários, suas famílias e todos os habitantes. Trata-se, igualmente, de discernir entre os benefícios atribuíveis à iniciativa aqueles que são monetários e aqueles que não são. No contexto de uma estratégia de desenvolvimento territorial baseada no fortalecimento de iniciativas de auto-organização em redes locais de economia solidária, três perguntas podem orientar o processo de monitoramento na agenda de uma outra gestão: como construir a viabilidade das iniciativas?; b) como planejar a gestão das iniciativas?; c) como avaliar a sustentabilidade das iniciativas? Levando-se em conta a importância de uma redefinição da noção de sustentabilidade para o fortalecimento da agenda da outra gestão, nos concentraremos a seguir sobre a terceira questão para apresentá-la e ilustrá-la com dois exemplos de ferramentas que se aplicam.

Para a outra gestão, a ancoragem territorial levanta uma questão prática sobre os meios de avaliação. O princípio da viabilidade financeira não é adequado para inúmeras iniciativas que desenvolvem uma abordagem ampla da economia. Elas fazem isso de três maneiras diferentes: remodelando as práticas de mercado por meio de regras de cooperação e solidariedade; mobilizando recursos não mercantis junto às instituições parceiras - públicas ou não públicas -; ou incentivando o uso de recursos não monetários. Portanto, a outra gestão precisa recorrer a modalidades híbridas de financiamento e a formatos institucionais mais amplos para a viabilidade econômica das iniciativas. Assim, a questão da sustentabilidade merece ser redefinida antes de considerar sua avaliação. Em particular, a sustentabilidade deve ser considerada em sua relação com a viabilidade financeira. Numa lógica de mercado, o grau de sustentabilidade de uma iniciativa é essencialmente abordado atra- 
vés de sua viabilidade financeira. Este último é visto como uma maneira de gerar autonomia e autossuficiência da iniciativa em relação ao seu ambiente. Para a outra gestão, pelo contrário, a sustentabilidade de uma iniciativa não se reduz ao problema de viabilidade financeira, uma vez que o objetivo e o contexto de ação das iniciativas vão além do contexto estritamente comercial.

De fato, como vimos antes, iniciativas portadoras de uma outra gestão buscam, antes de tudo, atender às necessidades locais em um determinado contexto territorial. Elas tendem a promover modalidades renovadas no que diz respeito à relação entre o econômico e o social, ou entre a democracia e a economia. Elas também têm a vocação de gerar resultados tanto para os atores individuais quanto para o território local onde estão inseridas. Nesse contexto mais amplo, a utilidade social vem se substituir a viabilidade financeira enquanto a finalidade do modo de gestão e suscitar a formulação de novos instrumentos de avaliação. Como a utilidade social se concentra na vida humana, no contexto do projeto, na necessidade do projeto em seu contexto, a outra gestão, guiado pela utilidade social, não está subordinada à viabilidade financeira. Ela pressupõe uma perspectiva multidimensional de sustentabilidade baseada nos aspectos socioeconômicos, sociopolíticos, socioculturais, sociotecnológicos e socioambientais. Essas cinco dimensões traduzem juntas, e de maneira combinada, o sentido da utilidade social e sua sustentabilidade. O desafio de uma ferramenta de avaliação reside então em sua capacidade de entender melhor essa multidimensionalidade da sustentabilidade em ação na prática da outra gestão. Isso é concebido como uma avaliação da utilidade social.

\section{Sustentável, mas não viável: o desafio da outra gestão}

Vimos que a problemática da outra gestão se formula com o propósito de desconstruir a assimilação da ideia de sustentabilidade à noção de viabilidade financeira. Dois casos de figura aludindo essa relação devem ser resgatados então para tornar mais claro o posicionamento da outra gestão: 
a) viável mas não sustentável: no ambiente institucional de mercado encontram-se incontáveis situações de empresas consideradas altamente viáveis em razão do elevado nível de rentabilidade auferido como resultado financeiro da atividade concebida como um negócio, mas que não se mostram ao mesmo tempo sustentáveis, em razão dos efeitos de externalidades negativas gerados pela atividade ou negócio da empresa. Tais efeitos podem ser de natureza socioambiental quando se referem aos diferentes tipos de impacto que agridem ou degradam o meio ambiente ou de natureza sociopolítica quando se referem ao não reconhecimento de direitos de grupos sociais envolvidos com a atividade ou a manipulação de regras éticas de conduta, entre outros casos;

b) sustentável, mas não viável: no ambiente institucional da sociedade, encontram-se inúmeras situações em diferentes tipos de organizações cujas iniciativas criadas são capazes de adquirir grande força em termos de legitimidade territorial através da sua utilidade social, ou seja, da sua capacidade em atender diferentes necessidades da população no seu território. Porém, essas mesmas iniciativas mostram-se não viáveis no sentido em que não são capazes de produzir seu autofinanciamento sob condições de mercado.

Grande parte das organizações almejam um terceiro caso de figura, aquele do "viável e sustentável", incluindo aí aquelas inscrevendo-se numa lógica de outra gestão. Porém, neste caso, reconhece-se que uma tal fórmula apenas tem condições de realizar-se quando se opera uma ressignificação das práticas mercantis. Ou seja, quando princípios éticos e solidários redefinem as próprias regras de mercado, conforme atestam diferentes experiências tais como o comércio justo, as finanças solidárias, a produção autogestionária, o consumo ético, entre outros casos de empreendedorismo coletivo e práticas cooperativistas renovadas, além das mais diversas formas de redes em economia solidária. A agenda da outra gestão privilegia então tanto esse terceiro caso que acabamos de indicar, quanto o segundo.

Se o primeiro caso é revelador de uma racionalidade assumida irracionalmente, conduzindo a necessidade de uma crítica radical, o segundo caso 
suscita uma reflexão sobre os meios de apoio e suporte necessários ao fortalecimento dessas iniciativas. É nesse sentido que ferramentas de avaliação da sustentabilidade, enquanto dispositivo inovador na agenda da pesquisa aplicada no campo da outra gestão, podem trazer contribuições relevantes. Elas podem ser vistas como um meio de revelar aquilo que normalmente não se mostra ou é invisibilizado na realidade da gestão. Isto é, os resultados substanciais que, pelo seu valor intrínseco, indicam os caminhos possíveis sob os quais gestores podem escolher para consolidar a outra gestão.

\section{Exemplo I: Matriz de avaliação da utilidade social e de autoavaliação}

A matriz de avaliação da utilidade social foi desenvolvida no Brasil através de experiências de pesquisa e extensão com incubação em economia solidária na UFBA. O objetivo da ferramenta é de apreender o grau de sustentabilidade de uma iniciativa, organização ou empreendimento no campo da outra gestão, em relação à capacidade de produzir utilidade social na sua prática. A ferramenta desloca, portanto, o elemento central de avaliação da sustentabilidade da noção de viabilidade econômico-financeira para a noção de utilidade social. Para tanto, ela assume o pressuposto segundo o qual a sustentabilidade apenas pode ser compreendida na sua multidimensionalidade.

A rigor, trata-se de uma ferramenta que se desdobra em duas. Uma delas para ser utilizada como instrumento de avaliação externa e a outra como instrumento de autoavaliação a ser utilizado pelo próprio grupo ou empreendimento objeto da avaliação. Em seu sentido amplo, a ferramenta busca explorar cinco dimensões da sustentabilidade na dinâmica de um empreendimento ou iniciativa em seu cotidiano: socioeconômica, sociopolítica, sociocultural, sociotecnológica e socioambiental.

A dimensão socioeconômica refere-se à capacidade da iniciativa de gerar e mobilizar os recursos necessários para o desenvolvimento de suas atividades. Com a ênfase na ideia de recurso, amplia-se a percepção da prática econômica em análise: trata-se de compreender a capacidade da organização 
de reproduzir materialmente suas condições de existência, de sobrevivência ou de sustentabilidade, para além da percepção apenas dos recursos financeiros. Para isso, essa dimensão articula três critérios de avaliação informando sobre três lógicas socioeconômicas distintas, conforme uma concepção substantiva de economia: a lógica mercantil, a lógica redistributiva - ou não mercantil - e a lógica reciprocitária - que em grande medida é não monetário. Com a lógica mercantil, a sustentabilidade é avaliada através da capacidade da iniciativa de gerar renda e/ou receita financeira a partir de relações de produção e comercialização. Essas são as práticas econômicas usuais associadas às relações de compra e venda em um ambiente de mercado. Numa lógica redistributiva, a sustentabilidade é apreendida através da capacidade da iniciativa em mobilizar recursos por meio de parcerias, acordos e/ou contratos de financiamento junto a instituições e atores da sociedade em geral, sobretudo entes públicos - governamentais e não governamentais -, mas também entes privados. A lógica redistributista difere do princípio da competição, pois ao invés de uma relação de troca mercantil ela estabelece um mecanismo de transferência direta de recursos fundado nos princípios de subvenção ou subsidiariedade que se justificam pela natureza de utilidade social da prática que é financiada. Por fim, a lógica reciprocitária informa sobre a capacidade de geração de recursos, sobretudo não monetários, através de variados mecanismos de cooperação e solidariedade econômica como a troca solidária de bens e serviços, a mutualização e partilha de recursos, a produção para o autoconsumo ou a ajuda mútua, entre outros. Além dessas formas não monetárias de economia, a lógica reciprocitária compreende também a capacidade em mobilizar recursos monetários através dos mais variados mecanismos de financiamento coletivo baseados no princípio reciprocitário.

A outra gestão está interessada no equilíbrio dessas três lógicas mencionadas, e muito especialmente, valoriza a subordinação da lógica mercantil aos imperativos de solidariedade que definem o propósito desse tipo de prática em análise. É a razão segundo a qual, tais iniciativas têm vocação para ressignificar o próprio princípio mercantil, quando as organizações estabelecem 
relações de mercado a partir de critérios éticos e princípios de cooperação e solidariedade através de atividades em rede. Nesse sentido, para preservar a sustentabilidade da iniciativa, no que diz respeito a essa dimensão socioeconômica, é necessário evitar que uma lógica se desenvolva em detrimento das outras duas, conforme costuma ocorrer com a lógica mercantil. Em termos de avaliação, é uma questão de saber se a iniciativa é capaz de mobilizar os recursos necessários para sua sustentabilidade recorrendo às diferentes lógicas de forma equilibrada. A avaliação procura ver até que ponto é possível que a iniciativa afirme sua inscrição no campo de uma economia substantiva e como ela pode desenvolver uma estratégia adaptada ao seu contexto de inserção e à sua natureza organizacional. A avaliação em relação à outra gestão garantirá, portanto, que a lógica do mercado respeite os princípios éticos e sociais fundamentais e que se criem mecanismos de solidariedade com instituições apoiadoras, bem como formas de mutualização de recursos tanto financeiros quanto não monetários. A capacidade de agir de maneira equilibrada entre essas diferentes lógicas econômicas demonstra a vitalidade da iniciativa.

A dimensão sociopolítica faz referência à capacidade de auto-organização ou de autoinstituição da iniciativa em análise. O intuito é de tentar perceber a capacidade de funcionamento perene de um grupo de pessoas trabalhando num objetivo comum. Isso é particularmente importante em um ambiente de exclusão social, quando os vínculos sociais são enfraquecidos pela degradação dos mecanismos de sociabilidade que impedem os processos democráticos de associação humana. Trata-se de um desafio de perenização de um processo de gestão de pessoas associadas que se vive como uma experiência de aprendizagem - ou de reaprendizagem em alguns casos - da capacidade de trabalhar em grupo - ameaçada com a ascensão dos valores individualistas no trabalho -, o que implica a construção lenta e gradual de uma cultura política democrática. Essa dimensão sociopolítica deve ser considerada em relação a um duplo aspecto inerente a dinâmica da iniciativa em análise: o primeiro é mais interno e concerne ao grau de autonomização do coletivo local - seus próprios participantes - no processo de gestão da sua 
própria iniciativa ou organização. Esse aspecto considera implicitamente o grau de democratização das relações e o nível de participação das pessoas como elementos centrais da avaliação, refletido no grau de autonomia da iniciativa ou empreendimento e o perfil do seu sistema de tomada de decisões. O segundo critério diz respeito à capacidade da iniciativa ou empreendimento em fomentar um modo de ação pública através da sua prática, que está inserida num dado contexto local. Esse aspecto afeta diretamente o nível e a forma de participação das pessoas na discussão dos problemas comuns ligados à vida cotidiana no lugar onde a iniciativa opera. Além disso, a possibilidade de fomentar ação pública se manifesta na capacidade da iniciativa em produzir articulação institucional, seja através da sua inserção em diferentes tipos de rede da sociedade civil - e para além dela -, seja através da sua capacidade em estabelecer pactos, interações e acordos ou contratos com autoridades públicas e as mais variadas instituições.

Se esses dois critérios assinalam a importância da dimensão sociopolítica na avaliação da sustentabilidade, o primeiro busca evidenciar o nível de aprendizagem de uma cultura política democrática dirigindo os processos decisionais internos. Já o segundo critério, para além de salientar inovações no domínio da cultura política local, informa sobre a capacidade da iniciativa em fomentar transformações no plano mais institucional da vida no território. O que se torna importante nesta dimensão é saber se a dinâmica da iniciativa ou organização permite reforçar dois aspectos salutares em termos de lógica de ação sociopolitica. O primeiro concerne o grau de autonomia e de responsabilização do grupo na gestão da iniciativa em si mesma, o que faz referência à capacidade de aprender o exercício de uma cultura política democrática de tomada de decisão coletiva num processo de autogestão. O segundo aspecto refere-se no nível de articulação da experiência, tanto na sua capacidade de participar de redes dentro da própria sociedade civil e fora dela, quanto em relação à sua capacidade estabelecer pactos, acordos, interações e parcerias com diferentes instituições, preservando sua autonomia. 
A pertinência dessa dimensão para a sustentabilidade através da realização da utilidade social repousa em sua importância para a estabilidade organizacional: como poderia uma ação empreendedora durar se as pessoas não conseguem trabalhar juntas? Dito de outro modo, estaria o grupo em condições de tomada de decisões coletivas ou de não funcionar enquanto coletivo? Ou ainda, como pode durar uma iniciativa neste caso sem basear-se em mecanismos de decisão democráticos ou sem que as pessoas implicadas não estejam realmente participando? Ou ainda, quando as pessoas não sao encorajadas a promoverem discussões públicas locais sobre seus problemas comuns e não são capazes de favorecer formas locais de ação pública? Enfim, como uma iniciativa que não interage com outras instituições - em pelo menos alguns dos mais variados níveis e escalas - pode ser sustentável? Em resumo, dois critérios principais orientam a análise da utilidade social nessa dimensão: capacidade em afirmar a autonomização dos participantes e capacidade em produzir ação pública ou fazer articulação institucional.

A dimensão sociocultural refere-se à capacidade da iniciativa em criar vínculos, tanto entre os membros e o coletivo que constitui a organização, quanto em relação ao contexto territorial no qual está inserido. A produção de vínculos representa uma base importante para a manutenção da iniciativa, pois sua perenização pressupõe níveis mínimos de identificação dos sujeitos entre si e da organização com o seu local. Esses vínculos podem ser ao mesmo tempo sociais e culturais. Do ponto de vista social, essa dimensão informa, de um lado, sobre a capacidade da iniciativa em gerar inclusão social, isto é, em fornecer condições para incluir nas suas atividades pessoas geralmente excluídas da dinâmica e dos processos de trabalho. Além disso, essa dimensão também informa sobre a capacidade da iniciativa em gerar coesão social. Ou seja, em trabalhar no fortalecimento da estima das pessoas envolvidas em suas atividades através do fomento à uma cultura de relações baseada em valores como solidariedade, cooperação e confiança. O exercício e aprendizagem de tais tipos de valores afetam diretamente a estrutura da sociabilidade no trabalho e representam uma base indispensável, em termos de capital social, para o desenvolvimento humano e realização dos demais objetivos 
da organização. Do ponto de vista cultural, essa dimensão informa sobre o grau de identificação das pessoas com a iniciativa e seu território, permitindo compreender o nível de enraizamento das atividades empreendidas no tecido da vida cultural do lugar.

Em termos de avaliação, trata-se de saber se a dinâmica da iniciativa é capaz de contribuir com o desenvolvimento humano, seja modificando a percepção que os sujeitos fazem de si mesmos - trabalho sobre a autoestima -, seja introduzindo ou reforçando valores como cooperação e confiança na vida cotidiana das pessoas. É também uma questão de saber se a iniciativa contribui para fortalecer a identidade e a cultura local. A pertinência dessa dimensão para a sustentabilidade e realização da utilidade social reside no fato de que o aspecto social - seja em termos de autopercepção individual ou de cooperação e confiança nas relações mútuas - constitui uma base fundamental para a estabilidade organizacional: como uma ação empreendedora poderá durar se as pessoas não confiam e nem cooperam entre elas, além de não sentirem-se plenamente capazes na sua estima enquanto sujeitos? Do mesmo modo, a construção de vínculos culturais locais constitui uma base fundamental para a estabilidade organizacional: como uma ação empreendedora pode durar se ela não se identifica com o território no qual se localiza - ou não dispõe de nenhum engajamento cultural no lugar? Ou seja, se não possui qualquer grau de enraizamento... Em resumo, os critérios orientando a análise da utilidade social nessa dimensão sociocultural são a inclusão social, a coesão social e o enraizamento cultural.

A dimensão sociotecnológica refere-se à capacidade de gerar e socializar conhecimentos em relação ao trabalho realizado pelo grupo na dinâmica da iniciativa, assim como, a transformação de alguns desses conhecimentos em tecnologias próprias. Trata-se, de fato, de perceber a capacidade da iniciativa em fomentar processos de aprendizagem através da sua ação. O objetivo é avaliar em que medida a iniciativa é portadora dessa capacidade de aprendizagem, quais conhecimentos ela produz e se existem soluções tecnológicas respondendo às exigências da atividade produtiva da iniciativa, seja através 
da suas próprias condições locais - ou seja, fazendo uso dos conhecimentos disponíveis localmente e que fazem parte do patrimônio cultural do território o qual encontra-se enraizado -, seja através de intercâmbios com outras experiências.

O que se torna importante nessa dimensão é conhecer a capacidade efetiva da iniciativa em gerar e em socializar conhecimentos em relação ao trabalho desenvolvido pelo grupo na sua dinâmica. Importa, então, saber se a organização se preocupa com a maneira na qual ela exerce suas atividades e o tipo de solução tecnológica que ela utiliza ou se ela não utiliza filtro algum em relação aos conhecimentos absorvidos do exterior. A intenção é de compreender como a iniciativa gera seu próprio processo de aprendizagem, já que o ideal da autonomia passa fundamentalmente pela consciência que se dispõe sobre seus próprios conhecimentos. A pertinência dessa dimensão para a sustentabilidade e a realização da utilidade social repousa sobre o valor da produção de conhecimento, do processo de aprendizagem, assim como da capacidade em gerar tecnologias próprias. Afinal de contas, como pode-se considerar durável ou sustentável uma iniciativa que não acumula conhecimentos, que não aprende com sua própria experiência e que não consegue refletir sobre as próprias condições de realização do seu trabalho ou dos seus objetivos? Em resumo, os critérios orientando a análise da sustentabilidade nessa dimensão são a produção de conhecimento e sua socialização, de um lado, e a geração de tecnologias sociais, do outro.

A dimensão socioambiental refere-se ao grau de vinculação da iniciativa com as características ambientais do seu território. Trata-se então de avaliar os níveis de impacto ecológico da ação em seu ambiente. Esses podem ser abordados em termos de controle de externalidades negativas geradas pela atividade produtiva ou em termos de produção de externalidades positivas. O objetivo é reconhecer o nível de reflexão e prática da iniciativa em relação ao meio ambiente e entender como essa atenção se reflete no cotidiano do coletivo. O que se torna importante nesta dimensão é poder avaliar em que medida a iniciativa exerce práticas de controle de danos ambientais, de um 
lado, e, em que medida a dinâmica da iniciativa é capaz de promover impactos positivos em seu meio ambiente.

A pertinência dessa dimensão para a sustentabilidade reside no pressuposto segundo o qual ter uma relação de equilíbrio entre a iniciativa e seu meio ambiente é uma condição elementar para a perenização das atividades e atingimento da sua utilidade social, que neste caso pode ser definida como uma utilidade ecológica. Afinal de contas, como pode-se considerar socialmente útil uma iniciativa que não reconhece as características ambientais do território onde está situado e não tem reflexão ou avaliação sobre o impacto da sua atividade nesse contexto? Em resumo, os critérios orientando a utilidade social nessa dimensão são, então, o controle de danos - ou controle de externalidades negativas -, de um lado, e a produção de externalidades positivas, do outro

Um jogo foi projetado para coletivos formados em torno de iniciativas solidárias para ajudá-las a se engajar em um processo de construção de significado pela mediação de uma lógica de autoavaliação de suas condições de sustentabilidade. Nesse tipo de abordagem, perguntas e respostas são feitas pelo grupo envolvido na iniciativa solidária. O jogo usa a metáfora do círculo (Figura 5) para aumentar a conscientização da ideia de um processo multidimensional altamente interligado. O jogo retoma as dimensões socioeconômicas, socioculturais, sociopolíticas, sociotecnológicas e socioambientais mencionadas acima. Cada dimensão é interrogada por meio de categorias e critérios de avaliação. O jogo convida os participantes a responder várias sequências de perguntas. Esse processo permite que os membros do coletivo julguem o progresso de sua iniciativa ou projeto. Durante o jogo, os membros do coletivo são incentivados a criar uma visão compartilhada da experiência que experimentam. Novos significados emergem durante o processo. Isso leva os membros do coletivo a refletirem sobre os problemas e desafios que enfrentam e sobre as possibilidades de mudanças ou inflexões na trajetória seguida. Para animar o jogo, o grupo dispõe de pequenos objetos - que podem ser "casas", por exemplo - que eles colocam em uma mandala. Para cada 
critério, o grupo possui de zero a três "casas" para avaliação. Ao final do jogo, obtemos uma fotografia da situação do coletivo em todas as dimensões avaliadas. Isso fornece uma visão geral da iniciativa. É importante enfatizar que o processo de avaliação leva o grupo a considerar soluções para resolver certas deficiências ou déficits que ele próprio identificou. A abordagem ideal típica é de fato um justo equilíbrio entre as diferentes dimensões que promovem a sustentabilidade da iniciativa. Um desequilíbrio - por exemplo, a predominância de recursos de mercado - pode levar o grupo a questionar a parte invisibilizada de sua ação. A transição de uma visão essencialmente orientada para o mercado para uma visão que integra outros critérios pode constituir a oportunidade para uma consciência coletiva da importância de uma gestão aberta ao conjunto das dimensões da iniciativa solidária. Trata-se de valorizar todas as dimensões do projeto e buscar as boas articulações e complementaridades entre elas.

Figura 5 - Mandala de autoavaliação reflexiva sobre a sustentabilidade

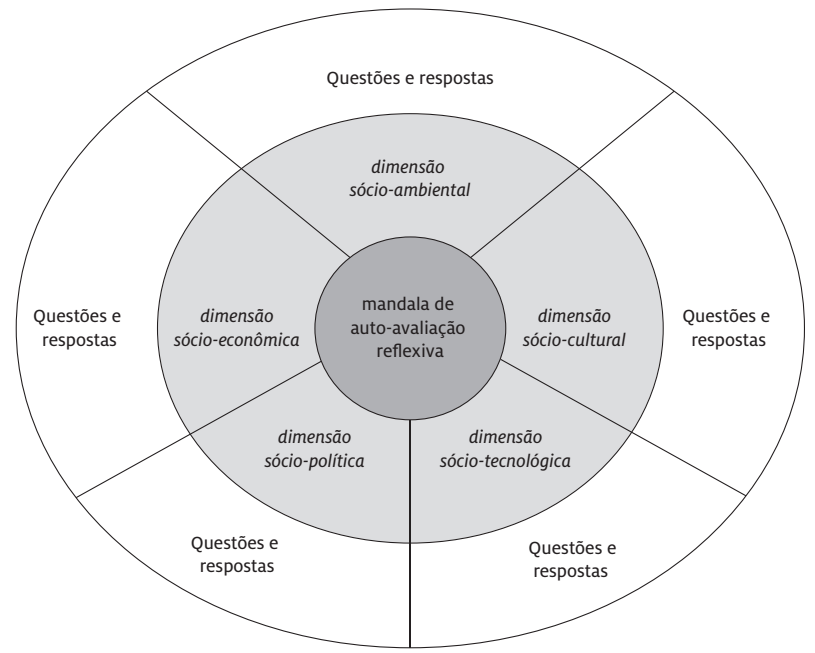

Fonte: adaptado de Eynaud e França Filho (2019). 


\section{Exemplo 2: Avaliação crítica da cifra}

Uma associação, em província francesa, agrupa dez funcionários permanentes e uma centena de voluntários em torno de três grandes domínios de atividade: um acompanhamento a escolaridade - no ensino básico e fundamental -, um acompanhamento a parentalidade, e, cursos de alfabetização para adultos em Francês como Língua Estrangeira (FLE). O FLE é uma aprendizagem do francês para pessoas cuja língua materna não é o francês. A associação observa que seu ambiente institucional está mudando fortemente - novos mecanismos, novas regras, novas modalidades na avaliação das ações. A antiga parceria firmada junto às autoridades públicas está para ser reconstruída. O futuro parece incerto, porque agora os financiadores públicos estão interessados principalmente na conformidade das ações associativas propostas com os objetivos nacionais das políticas públicas. Qualquer projeto associativo que não se encaixe na grade de análise é eliminado. Além disso, os projetos associativos não são abordados globalmente, mas decompostos atividade por atividade. Um exemplo emblemático dessa nova abordagem pode ser encontrado na vontade dos atores públicos de condicionar o financiamento das atividades do FLE a uma finalidade de inserção profissional e emprego. Mas o projeto da associação é o acompanhamento de populações que não se enquadram totalmente nesse único objetivo. Os debates ocorrem dentro da associação. Alguns acreditam que a atividade FLE da associação pode ser alinhada com os novos requisitos dos financiadores públicos. Eles defendem uma aproximação com os interlocutores dos financiadores públicos para encontrar um acordo. No entanto, outros membros da associação consideram que os representantes dos financiadores públicos não oferecem margem de manobra e que existe uma ameaça real à sobrevivência do projeto da associação. Outras associações da cidade já fecharam as portas e parece que isso não provocou emoção especial junto aos financiadores.

Acontece que as atividades do FLE começaram com o nascimento da associação. Elas ilustram de certa forma as competências específicas desenvolvidas pela associação ao longo de sua história. A aprendizagem FLE é assim 
realizada em pequenos grupos, com a presença de numerosos voluntários. Eles se engajam junto com os aprendizes em um relacionamento que vai além da relação professor-aluno. Eles buscam promover a inclusão social, criando relacionamentos privilegiados com (e entre) os diferentes participantes das formações. A ação FLE da associação entra em contradição com as práticas usuais que não buscam combinar aprendizado de idiomas e aprendizado social. As práticas usuais colocam a relação de aprendizagem em uma dimensão estritamente profissional e excluem as esferas familiar e doméstica da esfera de aprendizagem.

No contexto do novo ambiente institucional, financiadores públicos solicitam à associação indicadores de monitoramento. Eles condicionam a continuação do apoio financeiro ao FLE à obtenção desses indicadores. No entanto, o apoio do financiador público é essencial para a continuação da ação do FLE. Permite pagar as instalações onde os cursos são realizados. Os financiadores solicitam estatísticas sobre o número, idade e sexo das pessoas que participam dos cursos de FLE. De acordo com as estatísticas produzidas, os financiadores notaram que existe uma maioria de mulheres frequentando os cursos. Mas a prioridade das autoridades públicas é a luta contra o desemprego. Eles consideram que no contexto da sua estratégia deve ser dada prioridade aos homens nos cursos FLE pois teriam, a priori, maior empregabilidade. De fato, as mulheres que frequentam esses cursos não procuram emprego. A principal preocupação delas é aprender o francês para que possam ajudar seus filhos à noite, quando precisam fazer os trabalhos escolares. A associação repassa então o pedido dos financiadores aos voluntários responsáveis por assegurar os cursos gratuitamente. Ela demanda-lhes que incentivem os homens a irem para as aulas. Os voluntários protestam. Eles não querem fazer a seleção baseada em gênero em seus cursos. Eles não querem aderir às escolhas de políticas públicas às quais não concordam. A associação está em crise.

Diante dessa situação, os membros da associação buscam distinguir mensuração e avaliação. Para esse fim, é convocada uma assembleia geral extraordinária. A fim de se distanciar dos números produzidos, as informações 
sobre cifras - ou quantificadas - são discutidas coletivamente e democraticamente. Durante a reunião, algumas pessoas consideram que os números não deveriam ter sido enviados ao financiador. Outros respondem que uma organização solidária deve ser absolutamente transparente. Outros, ainda, sugerem que a informação não deveria ter sido transmitida sozinha, mas que deveria ter sido acompanhada por outros indicadores mais precisos para expressar a natureza do trabalho realizado pela associação e, assim, poder ser melhor compreendida a qualidade do serviço prestado. Os debates são prolongados e um dos fundadores da associação toma a palavra. Ele diz que, em sua opinião, não há oposição entre a expectativa do financiador e os objetivos da associação. Os olhares estão voltados para ele. Ele acrescenta que desde o início a associação tem como objetivo a integração profissional e o emprego. No entanto, ela o faz com uma profundidade temporal que é fruto de sua experiência. Hoje, o fortalecimento das habilidades de língua francesa para as mães aumenta a capacidade das mulheres de ajudar seus filhos à noite nas lições de casa. Ao fazer isso, melhoramos a integração e a empregabilidade dos jovens que chegarão ao mercado de trabalho em dez ou 20 anos. Essa observação ajuda a avançar no debate, removendo a primeira oposição entre a solicitação do financiador e o projeto da associação. Decide-se coletivamente discutir com o financiador público, argumentando que a prioridade de curto prazo que ele busca em termos de integração não deve ser às custas da empregabilidade futura dos jovens de hoje. Os voluntários concordam com esse princípio juntamente com os funcionários e decidem mobilizar o maior número possível de pessoas em torno dessa ideia, a fim de serem ouvidos pelo financiador público. Esse exemplo é uma demonstração da inteligência coletiva que pode se desenvolver em uma associação que pratica gestão democrática. A deliberação organizada em torno da produção de cifras permitiu adotar uma postura crítica. Esse processo conferiu um novo significado para a cifra. Esse significado é ainda mais forte porque está relacionado à história e à experiência da associação. 


\section{Uma outra ideia da ação: rumo a uma abordagem pragmatista da gestão}

Diante dos perigos que o ameaçam, "o homem está condenado a buscar segurança”. (DEWEY, 20I4, p. 23) Essa necessidade imperiosa envolve-o na busca de certeza. Assim, o homem moderno não pode se satisfazer com uma aproximação. Com o progresso da ciência, ele quer poder confiar em elementos factuais que o tranquilizem. Ele quer poder colocar números sobre a realidade para avaliá-la. No entanto, Dewey nos alerta sobre esse ponto. A certeza não é "o horizonte do pensamento". É antes "sua cruz, seu fardo, o risco que ele deve evitar, a tentação na qual se deve renunciar". (SAVIDAN, 20I4, p. I4) Para Dewey, a atração pela certeza é como o canto da sereia. É preciso se proteger dela pois "a certeza é um descanso que a inteligência nunca deve conhecer". (SAVIDAN, 20I4, p. I4) Ela nos desvia da ação e da prática. Dewey mostra que "o homem natural não gosta do desconforto que acompanha a experiência da dúvida e está pronto para agarrar qualquer coisa que lhe permita pôr um fim nela". (DEWEY 20I4, p. 244) Ele adverte, no entanto, contra "esse amor à segurança" que, segundo ele, "assume a forma de um desejo de não ser incomodado nem perturbado, levando ao dogmatismo, à internalização de crenças por respeito à autoridade, a intolerância e ao fanatismo, por um lado, e à uma dependência e à uma preguiça desresponsabilizante, por outro". (DEWEY, 20I4, p. 244) Nesse sentido, o pensamento de Dewey nos ajuda a inscrever a outra gestão em um processo experimental que recusa o dogma do mercado. De fato, a abordagem pragmatista coloca o primado da vida e da experiência humana, propõe um modelo de análise através da investigação social e está enraizada em uma abordagem de democracia radical.

Relacionado à reflexão sobre uma outra gestão, o pensamento pragmatista de Dewey é particularmente útil. Permite abrir a questão ética e a referência à vida humana. A abordagem investigativa de Dewey coloca "a inteligência humana a serviço da vida". (SAVIDAN, 20I4, p. I5) Ela rejeita a postura elitista "daqueles que colocam o pensamento nos picos mais altos apenas para garantir que não encontrem a plebe". (SAVIDAN, 2OI4, p. I6) Também rejeita 
a "separação secular da teoria e da prática", posicionando a "ação no centro das ideias". (DEWEY 20I4, p. I83) Para Dewey, "o conhecer é em si mesmo um tipo de ação". (DEWEY, 20I4, p. 184) Com a outra gestão, trata-se de reintroduzir os sentimentos humanos e, em particular, a solidariedade na ordem das prioridades. As decisões em gestão não são dissociadas - como vimos com a etnocontabilidade - das emoções e do relacionamento com o outro. É uma questão de reconhecer que "desejo, objetivo, planejamento só têm significação nas condições em que algo está em jogo". (DEWEY, 20I4, p. 242) Com a epistemologia do sul, a proposição pragmatista se abre para uma "epistemologia da emancipação que pode reconduzir a democracia aos seus poderes de invenção". (SAVIDAN, 20I4, p. I7) A certeza dá lugar a uma ética "que tende à demanda progressista, de melhorias e de reformas políticas e sociais contínuas". (SAVIDAN, 20I4, p. I5), como vimos nas iniciativas das incubadoras solidárias. Contra economistas ortodoxos que reivindicam sua cientificidade por omissão voluntária dos valores humanos, Dewey propõe aceitar perder "a certeza teórica se nós ganhamos em julgamento prático". (DEWEY, 20I4, p. I83) É exatamente a ambição de uma outra gestão que tende a dissociar medição e avaliação.

Para Dewey, o pensamento é "uma prática voltada para a resolução de problemas concretos". (SAVIDAN, 20I4, p. I5) Partindo do princípio que toda ideia verdadeira é uma ideia verificada experimentalmente, ele propõe desenvolver a investigação social. (DEWEY, 1967) Para ele, as ciências sociais devem confiar na experiência social, porque existe uma conexão íntima entre o conhecer e o fazer. A investigação social é pensada por Dewey como, ao mesmo tempo, um meio de aumentar o conhecimento factual das situações e de prever a reversibilidade das causalidades trazidas à luz por esta. Se a investigação social supõe uma instrumentação e uma tecnicidade, Dewey identifica três tempos na investigação experimental. Em primeiro lugar, "uma ação ostensiva" induz mudanças "no ambiente e no relacionamento que temos com ele". Em seguida, "uma atividade realizada com referência em ideias", satisfazendo as condições do problema identificado. Finalmente, uma "nova situação em- 
pírica" que é o resultado da ação conduzida e na qual "os objetos se encontram diferentemente religados uns aos outros". (DEWEY, 20I4, p. IO3) Esse encadeamento incessante de situações, problemas e resultados da ação coloca a "ação no centro das ideias". (DEWEY, 20I4, p. I83) As operações da vida real dão um novo estatuto às ideias. Elas não são mais abstratas e "não são mais meras ideias", mas "ideias experimentais e operacionais" que alimentam a inteligência. (DEWEY, 2OI4, p. I84) Portanto, "a realidade plena e final do conhecimento" está situada no nível do caso individual e "não no nível das leis gerais". (DEWEY, 20I4, p. 224) Aqui, novamente, a contribuição para a outra gestão é importante. Através da reversão de causalidades, o processo coletivo de investigação social tem por vocação desaguar numa transformação social cuja configuração não está dada a priori, mas é construída numa troca.

Dewey diz em seu discurso "Creative democracy, the task before us", pronunciado em I939: "A democracia em relação a outros modos de vida é a única que acredita sinceramente no processo da experiência tanto como um fim quanto como um meio". Sua recusa do especialista e das posições dos atores que se julgam acima dos outros coloca Dewey em uma postura próxima aos modelos de educação popular. Para Dewey, trata-se realmente de se engajar numa democracia criativa (JOAS, 2008) sem concessão. O foco está nas "dimensões comunicativas da ação e nos processos permitindo imaginar através da deliberação as soluções criativas diante de situações problemáticas". (RENAULT, 20II, p. I69) O interesse da postura pragmatista é que ela permite visualizar um aprofundamento da democracia ou, dito de outro modo, a possibilidade de democratizar a democracia. (CALLON; LASCOUMES; BARTHE, 200I) A dimensão criativa face aos problemas lembra os trabalhos de Follet, que eram próximos a esses dos pragmatistas. Assim, para Follett, a gestão participa de um aprendizado permanente, de experimentações e de trocas criativas. (FOLLETT, 195I) Em situações de gestão, os atores são levados a se colocarem lado a lado, a se influenciarem ou a se confrontarem. Trata-se, para Follett, de comportamentos normais e o conflito não deve ser evitado. Ele é construtivo. Follett demonstra assim que existem três maneiras de resolver um conflito: a dominação de um ator sobre o outro; a negociação seguida de 
um consenso; e, o uso da criatividade pela invenção de uma solução inédita. Follett chama essa terceira opção de "conflito construtivo". Nesse caso, trata-se de evitar tanto a manutenção da dominação quanto a crise resultante da impossibilidade de consenso. Follett coloca, desse modo, a criatividade a serviço da resolução de conflitos e valoriza o debate interno como produtor de significação. (FOLLETT, I95I)

\section{Por uma outra gestão}

A outra gestão que tentamos definir em torno desse panorama de propostas e metodologias faz parte de uma renovação do pensamento organizacional. Em conclusão deste capítulo, é possível propor várias definições não exclusivas da outra gestão. As discutiremos em dez pontos: I) a gestão substantiva; 2) a gestão democrática; 3) a gestão do território; 4) a gestão de mercadorias fictícias; 5) a gestão da reconciliação; 6) a gestão da inovação social; 7) a gestão dos comuns; 8) a gestão do outro; 9) a gestão experimental; e Io) a gestão do bem viver.

I. A outra gestão se opõe ao modelo formal e funcionalista. Ela rejeita a racionalidade calculadora em favor da racionalidade substantiva em valor. A outra gestão postula que as necessidades humanas não são ilimitadas e que a escassez não orienta todas as decisões de gestão. A outra gestão dialoga com a economia heterodoxa, se expressa na economia solidária e se desdobra em uma economia plural. A outra gestão é, então, em primeiro lugar, a gestão da outra economia;

2. A outra gestão coloca a democracia no centro das questões organizacionais e visa enriquecê-la no âmbito da governança democrática. Ela se constrói em torno de questões de inclusividade e de abertura a todas as partes interessadas. Ela almeja o compartilhamento ampliado e igualitário da decisão como um princípio gestionário. Ela pratica a transparência das informações com todas as partes envolvidas. Ela protege os denunciantes. ${ }^{2}$ A outra gestão é a gestão democrática;

2 Os denunciantes neste caso são os lanceurs d'alerte ou whistle-blower. O termo faz alusão a uma pessoa que tendo conhecimento de um perigo para os seres humanos, a sociedade, a economia ou o meio-ambiente, envia publicamente um sinal de alerta dirigido às autoridades e à imprensa. 
3. A outra gestão inicia um processo de desmercadorização em múltiplos níveis - institucional, sociopolítico, sociocultural, socioeconômico, socioambiental - e em várias escalas -individual, comunitário, em rede. Isso só pode ser feito com referência a um território no qual as iniciativas solidárias se enraízam. A outra gestão é a gestão de um território de solidariedades;

4. Mostramos em seguida que a gestão poderia se associar com sucesso ao necessário processo de desmercadorização de mercadorias fictícias. Descrevemos como as moedas sociais - conversíveis ou não poderiam fazer parte de um trabalho de ressignificação da economia e participar de uma reapropriação democrática da gestão de atividades financeiras. Testemunhamos a desmercadorização do trabalho realizado pelas cooperativas de atividade e emprego e pelas cooperativas de plataforma. Por trás dessas iniciativas, se desenha com brilhantismo a proposta emancipatória de um trabalho associado. Este, consiste em devolver a autonomia e o poder àqueles que se engajam numa atividade individual, oferecendo-lhes uma estrutura coletiva de tipo cooperativo, na qual são membros associados. No que diz respeito à natureza, vimos como uma abordagem de incubação solidária poderia levar à preservação da riqueza natural e da biodiversidade de uma vila com a escolha do turismo responsável e comunitário, além de outras práticas articuladas em rede. Isso nos leva a formular outra definição. A outra gestão é a gestão da desmercadorização do trabalho, da moeda e da natureza;

5. A outra gestão abre a possibilidade de reconciliação entre a economia e o social. Ela se constrói na conjunção de uma gestão participando de uma governança democrática e de uma gestão guiada por um propósito de utilidade social. A outra gestão é a gestão da reconciliação;

6. Para enfrentar os desafios da outra economia, a outra gestão deve, então, demonstrar inovação social. Para se proteger de uma eventual instrumentalização, ela deve ser ancorada territorialmente e gerida democraticamente. A outra gestão é então a gestão de uma inovação social de tipo solidária;

Diferentemente de um delator, o denunciante neste caso tem uma motivação desinteressada. Ou seja, trata-se de uma atitude orientada segundo princípios de defesa do bem comum e/ou do interesse geral, o que justifica seu direito de proteção. 
7. A outra gestão se constrói por e com coletivos autogestionários e auto-organizados. Ela se funda na mutualização e no compartilhamento de recursos. Ela integra a abordagem dos movimentos de software livre e das cooperativas de plataforma e compartilha sua cultura. Ela inova produzindo suas próprias regras em um processo deliberativo. A outra gestão é a gestão dos comuns;

8. A outra gestão se inscreve nas abordagens compreensivas, alimentadas pelas contribuições da antropologia, da psicanálise e das ciências da educação. Nesse sentido, a outra gestão baseia-se na vida humana e nas preocupações éticas que organizam a vida em sociedade. Ela se elabora numa abordagem empática e preocupada com a humildade e o reconhecimento do outro. A outra gestão é uma questão de EP. Ela recusa a mercantilização do humano e das relações humanas. Ela vive desde muito tempo do vínculo convivial e amigável. A outra gestão é a gestão do outro;

9. A outra gestão é uma questão de experimentação, de criatividade e de democracia radical. Como tal, a outra gestão é fortemente influenciada pela abordagem pragmatista. Ela recusa a rigidez do pensamento que recobre a pretensão de certeza e o dualismo do pensamento formal. Ela o faz em uma dupla abordagem: de reintegração da economia no social e de aprofundamento da democracia. Isso é feito investigando coletivamente os problemas que se apresentam e experimentando soluções inéditas decorrentes de um conflito construtivo. Ela desenvolve sua ação pacientemente em uma perspectiva de melhoria. A outra gestão é a gestão da experimentação e da investigação social;

Io. A abordagem ameríndia compartilha com os autores pragmatistas a rejeição cartesiana da separação ontológica entre o homem e a natureza. Ela está ancorada no respeito pelo equilíbrio da vida e da natureza. O ideal coletivo do bem viver que ela carrega refuta o modelo de dominação baseado em uma lógica privada e se opõe à apropriação da riqueza material por um pequeno grupo às custas da maioria. A outra gestão está enraizada na vida social e democrática. Ela é a gestão do bem viver. 
Diante dessa diversidade de definições da outra gestão, muitas perspectivas são oferecidas. Elas ajudam a definir direções para um futuro programa de pesquisa. Alguns dos critérios mencionados já foram colocados:

superação de oposições binárias e reducionistas, desconstrução de discursos gerenciais dominantes, afastamento crítico em relação à deriva gerencialista, à instrumentalização crescente que a acompanha e aos seus malfeitos sobre a organização, sobre os trabalhadores e sobre a sociedade, abordagem conceitual, longitudinal e histórica dos fenômenos estudados para melhor compreender os mecanismos em marcha. (DIETRICH; PIGEYRE; VERCHER-CHAPTAL, 20I5, p. I77)

Outras perspectivas podem ser adicionadas. Dentre elas, destacamos: I) um reinvestimento na pluridisciplinaridade; 2) o estudo dos fundamentos de uma gestão substantiva; 3) a exploração de outras gestões; 4) a preservação de outras gestões; 5) os novas indicadores de gestão; 6) os vínculos entre gestão e ação pública; e 7) a abertura de um diálogo norte-sul em matéria de gestão solidária.

I. Se as ciências da gestão constituem uma disciplina relativamente aberta para as outras disciplinas, percebe-se que essa abertura não é igual segundo as disciplinas consideradas. Assim, a proximidade com a economia é muito mais forte do que com a sociologia, a antropologia ou a educação. Essa diferença é notável e leva a uma redução do interesse das ciências da gestão por abordagens compreensivas e qualitativas. Esse desequilíbrio de abertura no seio das ciências sociais é acentuado por um diálogo fraco com as ciências humanas especialmente com a história, como vimos no primeiro capítulo deste livro. Um primeiro campo de trabalho pode então consistir num reinvestimento na pluridisciplinaridade, privilegiando as disciplinas menos exploradas das ciências humanas e sociais;

2. Vimos a importância de uma abordagem substantiva para poder pensar uma outra gestão. Isso implica que o pesquisador em ciências da gestão desenvolva o estudo das lógicas reveladas por Polanyi como a reciprocidade, a redistribuição e o compartilhamento doméstico. 
As abordagens de tipo antropológico e etnográfico estão em condições de servir a esse projeto. Eles tornam possível estender a pesquisa organizacional para além do gerenciamento formal, em direção à gestão substantiva;

3. Temos constatado que um dos limites das ciências da gestão é restringir a questão organizacional ao campo da empresa. Ao fazer isso, a gestão se refere muito mais a uma teoria única das organizações do que às teorias da organização. A abertura e o aprofundamento da reflexão organizacional para além da empresa é desejável. O interesse deve ser dirigido, especialmente, para as organizações não capitalistas - associações, cooperativas, organizações mutualistas. Esse interesse precisa se traduzir por uma pesquisa dedicada para evitar a reutilização inadequada dos conceitos de gerenciamento de negócios. O objetivo é, então, de desenvolver uma pluralidade de abordagens conceituais organizacionais em relação estreita com a pluralidade de formas organizacionais não mercantis encontradas no campo;

4. A análise dessas formas de organização não poderá compensar a hegemonia das formas de organizações mercantis. Uma parte do trabalho de pesquisa sobre outras formas organizacionais não mercantis e não monetárias deve, portanto, ser dedicada aos meios de preservar a sociodiversidade do nosso tecido econômico. Isso pode ser feito explorando formas cruzadas de cooperação econômica democrática - combinando as lógicas de reciprocidade, de redistribuição, de compartilhamento doméstico e de mercado ressignificado - a serviço da finalidade de utilidade social;

5. Uma reflexão foi realizada entre economistas, especialmente através dos trabalhos da comissão Stiglitz sobre novos indicadores de riqueza, a fim de construir abordagens macroeconômicas mais fiéis à realidade social. O objetivo dessa Comissão era desenvolver uma reflexão propícia a ir além das medidas estritamente quantitativas do desempenho coletivo. Um mesmo trabalho deve ser feito nas ciências da gestão para produzir novas abordagens em matéria de avaliação. Trata-se de desconstruir as abordagens reducionistas em termos de performance de mercado e de impactos. Elas são incapazes de dar conta da riqueza de projetos associativos e apresentam o risco de distorcê-los. 
O intuito, ao contrário, é de desenvolver e promover abordagens que permitam distinguir mensuração de avaliação, a fim de encontrar dinâmicas virtuosas em termos de inteligência coletiva;

6. A gestão deve se colocar a serviço da transição ecológica e social. Para isso, é sem dúvida necessário desenvolver pesquisas em conexão com os profissionais da economia social e solidária, a fim de projetar as linhas de uma gestão voltada para a ação pública. Até o momento, a administração esteve excessivamente ligada à gestão de empresas para poder imaginar esse papel. Uma gestão conceptualizada na interação com associações pode, especialmente, permitir a gestão vislumbrar outros horizontes, não redutíveis aos limites funcionais das organizações de mercado. É uma questão de analisar como organizações privadas podem se colocar ao serviço de uma ação pública renovada;

7. Mostramos neste livro a importância de um descentramento das análises em termos de gestão. Esse descentramento pode ser obtido pela profundidade da análise histórica. Também pode ser obtido por um deslocamento geográfico na direção sul do mundo. É chegada a hora de sair do diálogo norte-norte e liberar a gestão da análise de mercado em que a visão anglo-saxônica tende a confiná-la. Para isso, um diálogo norte-sul em torno de uma gestão imbricada na vida humana é necessário. Este livro, escrito em duas vozes e abrangendo dois hemisférios, testemunha esse desejo. 